\title{
Review
}

\section{Aquaculture and agriculture-by products as sustainable sources of omega-3 fatty acids in the food industry}

\author{
Paz Otero ${ }^{1}$, Maria Carpena ${ }^{1}$, Maria Fraga-Corral ${ }^{1,2}$, P. Garcia-Oliveira $^{1,2}$, A. Soria-Lopez ${ }^{1}$, \\ Francisco J. Barba ${ }^{3, \star}$, Jianbo Xiao ${ }^{1, \star}$, Jesus Simal-Gandara ${ }^{1, \star}$, Miguel A. Prieto ${ }^{1,2}$ \\ ${ }^{1}$ Universidade de Vigo, Nutrition and Bromatology Group, Department of Analytical and Food Chemistry, Faculty of Sciences, 32004, \\ Ourense, Spain \\ ${ }^{2}$ Centro de Investigação de Montanha (CIMO), Instituto Politécnico de Bragança, Campus de Santa Apolonia, 5300-253 Bragança, Portugal \\ ${ }^{3}$ Nutrition and Food Science Area, Preventive Medicine and Public Health, Food Science, Toxicology and Fo-rensic Medicine Department, \\ Universitat de València, Faculty of Pharmacy, Avda, Vicent Andrés Estellés, s/n, Burjassot, 46100 València, Spain
}

\section{ARTICLE INFO}

\section{Article History}

Received 1 November 2021

Accepted 6 December 2021

\section{Keywords}

omega3 fatty acids

food waste valorization green extraction technologies

\begin{abstract}
A B S T R A C T
The valorization of by-products is currently a matter of great concern to improve the sustainability of the food industry. High quality by-products derived from the food chain are omega-3 fatty acids, being fish the main source of docosahexaenoic acid and eicosapentaenoic acid. The search for economic and sustainable sources following the standards of circular economy had led to search for strategies that put in value new resources to obtain different omega-3 fatty acids, which could be further employed in the development of new industrial products without producing more wastes and economic losses. In this sense, seeds and vegetables, fruits and crustaceans by products can be an alternative. This review encompasses all these aspects on omega-3 fatty acids profile from marine and agri-food by-products together with their extraction and purification technologies are reported. These comprise conventional techniques like extraction with solvents, cold press, and wet pressing and, more recently proposed ones like, supercritical fluids fractionation and purification by chromatographic methods. The information collected indicates a trend to combine different conventional and emerging technologies to improve product yields and purity. This paper also addresses encapsulation strategies for their integration in novel foods to achieve maximum consumer acceptance and to ensure their effectiveness.
\end{abstract}

(C) 2021 The Authors. Publishing services by Visagaa Publishing House This is an open access article distributed under the CC BY-NC 4.0 license (https://creativecommons.org/licenses/by/4.0/).

\section{INTRODUCTION}

There is an increased consumer request towards foodstuffs which provides health benefits. Lipids play an important role in the storage of energy and are essential in the membrane constitution. The different lipid diet sources have different significance owing to their composition of fatty acids (FA) which range between 2 and 36 carbon atoms. In animal and plant fats, FA are mainly present in a chain-length of 14-22 carbon atoms, with 0-6 double bonds [1]. Depending on their degree of saturation in the carbon chain, they can be divided into saturated fatty acids (SFAs) if no double bonds are present, monounsaturated fatty acids (MUFAs) with only one double bond and polyunsaturated fatty acids (PUFAs), if two or more double bonds are present (Figure 1) [2]. Within the PUFAs, two main groups called omega-3 $(\omega 3)$ and omega$6(\omega 6)$ FA are essential FA (EFAs) for humans because they are unable to biosynthesize them. The two major $\omega 6$ PUFAs consumed in the diet are linoleic acid (18:2; $\omega 6$; LA) and arachidonic acid (20:4; $\omega 6$; ARA) and the three main $\omega 3$ PUFAs are $\alpha$-linolenic acid $(18: 3 ; \omega 3 ; \mathrm{ALA})$, eicosapentaenoic acid $(20: 5 ; \omega 3$; EPA), and docosahexaenoic acid (22:6; $\omega 3$; DHA) $[3,4]$. ALA $(18: 3 ; \omega 3)$ should be differentiated from $\gamma$-linolenic acid (GLA) that is also $18: 3$ but an $\omega 6$ FA [4]. The $\omega 3 \mathrm{FA}$ are important nutrients with potent health benefits for the human body and brain. They act on the immune and nervous systems, being essential for the maintenance of normal brain function and also act on the cardiovascular system due to its antithrombic and antiarrhythmic effects $[5,6]$. Recommendations for minimum dietary intake of EPA plus DHA vary between 250-450 $\mathrm{mg} /$ day, especially for pregnant women and those of reproductive age [1]. In this sense, the increased demand for products preventing from cardiovascular diseases in combination with EPA and DHA essential supplementation due to non-synthesis in human body, makes the development $\omega 3$ FAs an important product to establish in European nutraceutical markets [7]. Besides, in the current Covid19 pandemic situation, the employment of $\omega 3$ supplements can be considered as a supportive therapy and a prevention strategy in SARS-Cov-2 infection, managing the "cytokine storm" and treating the cardiovascular complications associated to the illness [8]. Also, there is an evidence to suggest that n-3 PUFAs play a role in depression and mental disorders affecting mood population [9]. Thus, the demand for $\omega 3$ rich products is increasing worldwide and is expected to continuing growing. 


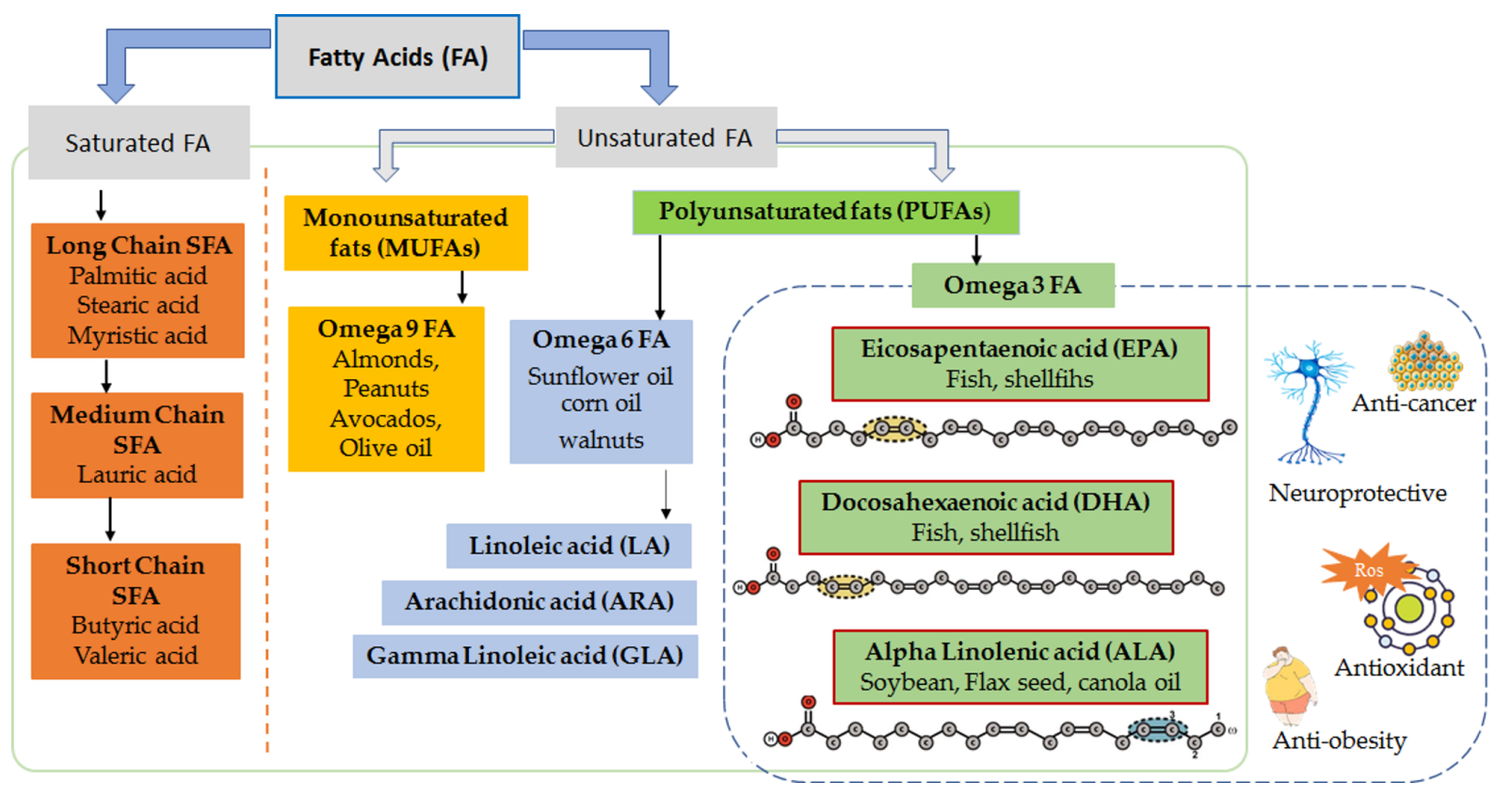

Figure 1 Fatty acids classification and main food sources.

Up to now, fish oil is considered the main source for $\omega 3$ FA production (especially those from sardines and anchovy), although alternative sources based on algae have reached the market [10, 11]. For example, Omega 3 Vegan Lineavi, a dietary supplement product containing extracts of Schizochytrium sp. algae oil is sold as a vegan friendly source of the healthy fats. The first attempts to collect $\omega 3$ rich oil were connected to fishery and thus today many companies selling product lines based on $\omega 3$ FAs have their origin in the fishing sector. For instance, the Norway company GC Rieber Oils were manufacturing fish oil until it started focusing on the production and commercialisation of $\omega 3$ rich products under the brand VivoMega ${ }^{\mathrm{TM}}$ in 2011 . Thus, the global market for $\omega 3 \mathrm{FA}$ is dominated by products derived from fish oil and most products on the market contain combinations of DHA and EPA as both FA are present in fish oil representing a higher market share than from vegetable sources being rich in ALA [12]. Aquaculture is the sector that consumes the most fish oil, accounting for about $70 \%$ of global demand [13]. Whereas only a small fraction (5\%) of global fish oil production is used to produce functional food for humans.

The $\omega 3$ FA markets have an important challenge related to the rising prices of fish oils due restrictions on fishing in high sea areas or the increasing aquaculture cost [14]. The use of fish oil as the main source for $\omega 3$ products has to be reduced in the upcoming years, due to more sustainable and cheaper plant-based sources, like nuts and seeds (e.g. chia or flax seeds, canola and soybean-based) [15]. Also, other fish species as well as crustaceans and mollusks can be an alternative $[16,17]$. To meet sustainable optimisation strategies and further focus on high value PUFAs, new process and productions are being investigating. One example is the company Cargill from US together with the German BASF 29 BASF which have designed in 2016 the $\omega 3$ rich canola oil, an alternative to fish oil in aquaculture feed, commercialising under concentrated $\omega 3$ FA powders (Dry n3 Powders).
In parallel, the production of foods worldwide has increased quickly due to the growing population in the recent decades [18] . Consequently, the production of food waste has also increased, leading to serious environmental problems. In this sense, the valorization of food by-products for the recovery of high-added value compounds has gained attention in the recent years as an alternative to reduce wastes (García-Oliveira et al., 2020b) and several studies have reported the satisfactory recovery of diverse compounds from food by-products, including FA [19]. Following this trend, the present paper aims to critically review sustainable strategies for obtaining high quality FAs from by products, not only from fish but also crustaceans, cereals, fruits, and vegetables, following the green extraction technologies, the target FA and their encapsulation for their re-integration in the food systems. The oil can be encapsulated in so called soft-gel capsules or used as it is for being incorporation into other complex nutrient systems for dietary supplementation [20]. Fisheries produce a large quantity of byproducts, which can be classified into solid waste (heads, shells, tails, fins, viscera and shells and shellfish waste) and liquids (wastewaters produced during processing). Besides, agriculture by-products are sources of oils and FA, which can be widely applied for extraction or nutraceutical preparation. It is a fact that fish oil is a well-established source for $\omega 3$ FA supplementation and therefore, alternative sources may need more time to replace those on the market $[21,22]$. This has happened with companies producing $\omega 3 \mathrm{FA}$ from microalgae which had to invest in research and inform potential stakeholders and consumers about the positive impact of their products.

\section{LIPID COMPOSITION OF AQUACULTURE AND AGRICULTURE-BY PRODUCTS}

Currently, different varieties of food by-products are considered as a promising source of FA. In general terms, those by-products containing very high proportions of FA and consequently, the most 
studied are those obtained from fish (blue fish, white fish, and semifat fish), crustacean, cereals, fruits and vegetables. Furthermore, the predominant type of FA varies depending on the food, being fish and crustacean rich in PUFA such as EPA, DHA, whereas cereals, fruits and vegetables are rich in oleic acid (OA), palmitic acid (PA) and ALA [23].

\subsection{Fish, crustacean and mollusks by-products}

According to FAO, the amount of fisheries waste has grown in recent years, reaching 9.1 million tons in 2019. Considering this situation, these by-products are becoming a global concern and it is clearly necessary to reduce the amount of waste to guarantee the sustainability of fishing sector [24]. It has been estimated that fish processing generates diverse by-products, corresponding to a $15 \%$ of fish weight when gutting and scaling and even a $70 \%$ when filleting. Generally, these by-products are discarded and incinerated, but they have been also used for animal feed or biofuel production [25, 26]. However, numerous studies have found that fish by-products contain high concentrations of $\omega 3$ FAs (EPA and DHA) which exhibit beneficial health effects [27], so that fishing industries are interested in utilizing those by-products to extract these high-value compounds with the aim of their further use in different areas, such as nutritional supplements or functional foods [24]. Table 1 shows the major FA present in different by-products from fish species, being, among others, liver, viscera, trimming, skin, head and eyeball the most analyzed ones. According to total fat amount, fish can be divided into three great types: i) white fish or lean fish, ii) semi-fat fish and, iii) blue fish or fatty/oily fish. Cod, haddock, or tusk are some examples of white fish. They are known to contain lower fat concentrations and $\omega 3$ FA proportions than blue fish. For example, Falch and co-workers studied the FA composition in liver, viscera and trimming by-products of gadiform species (cod, haddock, saithe, tusk, and common ling) [28]. These authors found EPA and DHA in all those wastes, being viscera and trimming by-products the ones with the highest proportion of DHA (between 5.1-32.8\%) (Table 1). Comparing species, the highest DHA content was found in saithe trimming by-products (ling viscera and trimming) in which it was equal to $60-70 \%$ of total PUFA. On the other hand, EPA content was similar in all by-products of gadiform species. Their ranges varied between $3.6-13.3 \%$ and are equal to $11-35 \%$ of total PUFA (Table 1). Regarding blue fish, salmon, sardine or tuna are some examples of fatty fish, which are very rich in $\omega 3$ FA. Several studies found important amounts of EPA, DHA, PA and OA in liver, head, eyeball, viscera and skin of tuna, salmon and sardinella (Mkadem \& Kaanane, 2019a) (Table 1). The highest EPA proportion was for sardine by-products, in which its proportion was about $22 \%$, representing a $57 \%$ of total PUFA, following by sardinella species (skin, 10.4- 20.5\%) [29] and Atlantic Salmon (viscera, 8.5\%) [27] (Table 1). Finally, semi-fat fish contains intermediate proportions between blue and white fish. For instance, Watanabe and colleagues showed that liver of bonito is rich in PUFA, being between 50 and $60 \%$ of total FA, in which $8-15 \%$ correspond to EPA and 30 $33 \%$ to DHA [30]. In this same study, the authors studied bonito by-products (heart, stomach, spleen, gonad and pyloric cecum) composition resulting in high proportions of DHA (about 30\% of total FA) (Table 1). Likewise, high content of MUFA such as OA and
SFA such as PA has been also found in fish, being the range between 9-44\% for OA and between $13-22 \%$ for PA. Stearic acid (SA) was found in low proportions (about 3.8 and 7\%) in salmon, sardine and tuna by-products (Table $\mathbf{1}$ ).

Regarding crustacean, it has been described that around a $60 \%$ of the total body weight corresponds to the exoskeleton and heads, leaving only $40 \%$ of the weight destined for consumption [31]. There are less studies focus on obtaining FA from their by-products, since they usually contain lower PUFA, MUFA and SFA proportions than fish. For example, one study reported that heads, shells and tails of shrimp contain about $10 \%$ of EPA and DHA and up to $15 \%$ of PA and $10 \%$ of OA [32]. Similar results were also showed for snow crab, being EPA and DHA the $40 \%$ and $35 \%$ of total PUFA, respectively; while PA corresponded to a $38 \%$ of total SFA and OA the $18 \%$ of total MUFA [33] (Table 1). Finally, also few studies evaluating the FA profile of mollusks by-products (shells, viscera and heads) have been found in the literature. Recently, a study checked the FA profile of waste from Octopus tetricus (O. tetricus) and Sepioteuthis australis (S. australis) [34] (Table 1). Both species were rich in PUFA, being DHA and EPA the main FA of this group, with values of $14.19 \%$ and $12.3 \%$ in O. tetricus and $5.3 \%$ and $20.6 \%$ in S. australis, respectively. These by-products also contained significant amounts of SFA such as PA and SA. Specifically, in O. tetricus, PA and SA corresponded to the $13.2 \%$ and $6.9 \%$ of the total FA, while in S. australis, the content of these two FA was $17.6 \%$ and $6.7 \%$, respectively. Both species showed a low MUFA content, with OA as the main FA and present in values under 6\% [34] (Table 1).

\subsection{Cereal's by-products}

Nowadays, the production of cereals worldwide is enormous. Just to cite an example, UE produces about 156 million of tons of wheat and 7 million of tons of oat every year. As expected, the wastes derived for this production are also enormous, which are about $25 \%$ of total production of cereals [35]. These by-products are considered as an underexploited resource, which presents compounds with good nutritional values and could be used in food industry, animal feed and in bioethanol production. Various studies reported important FA concentrations in cereal by-products, awakening the interest of the food industries to re-valorize these residues [36-38]. Table 1 shows the FA profile of different cereal by-products. According reported studies, the most used by-product is the bran, consisting in the coat seeds and aleurone layer from the grinding of the cereal grains, after separating the endosperm. The bran contains an oily fraction rich in LA, PA and OA, but also ALA and SA in lower concentrations, ranging between 5-11\% for ALA and between 1-7\% for SA. Many studies show the FA profile of the bran oil in different cereals such as wheat, rice, oat, corn, rye and spelt (Table 1). LA is the most predominant compound with more $50 \%$ of total FAs and is equal to $90-95 \%$ of total PUFA in all bran oils of cereals, except in rice and oat bran oil, in which LA proportion is below $40 \%$ of FAs. 
Product

By-product

FA

Chemical

FA amount

structure

Type FA and total

content

Detection Ref

method

\section{FISH}

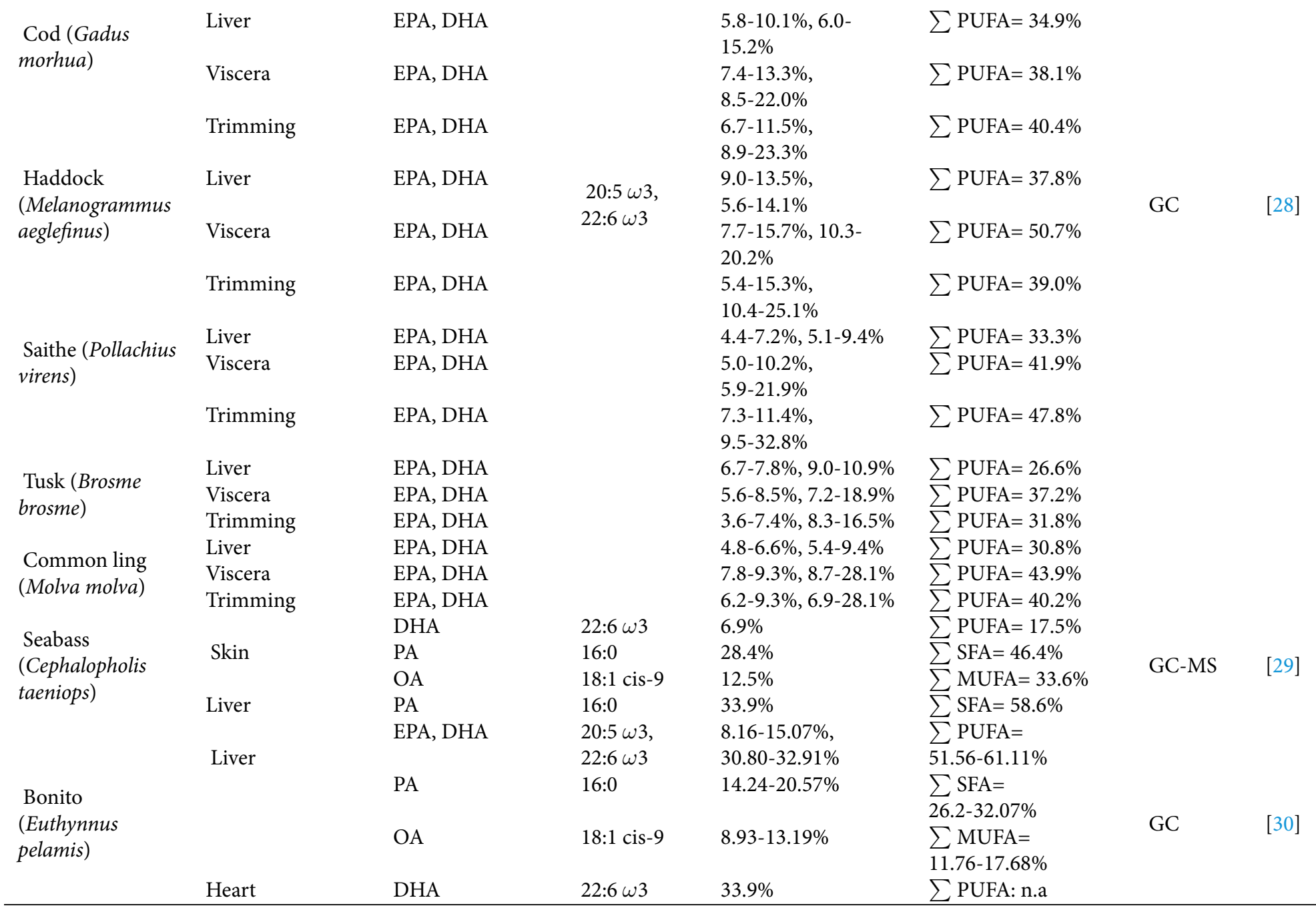




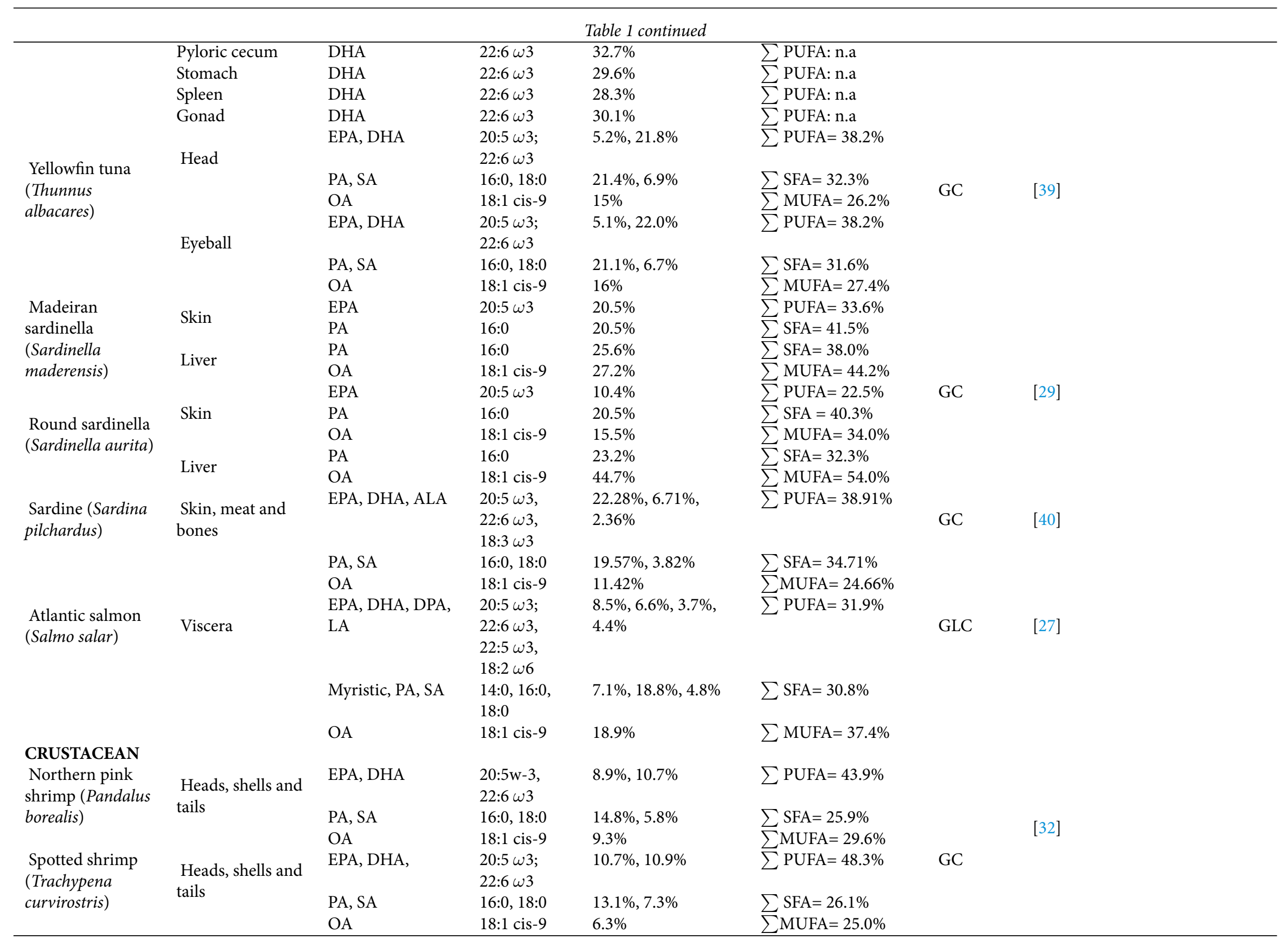




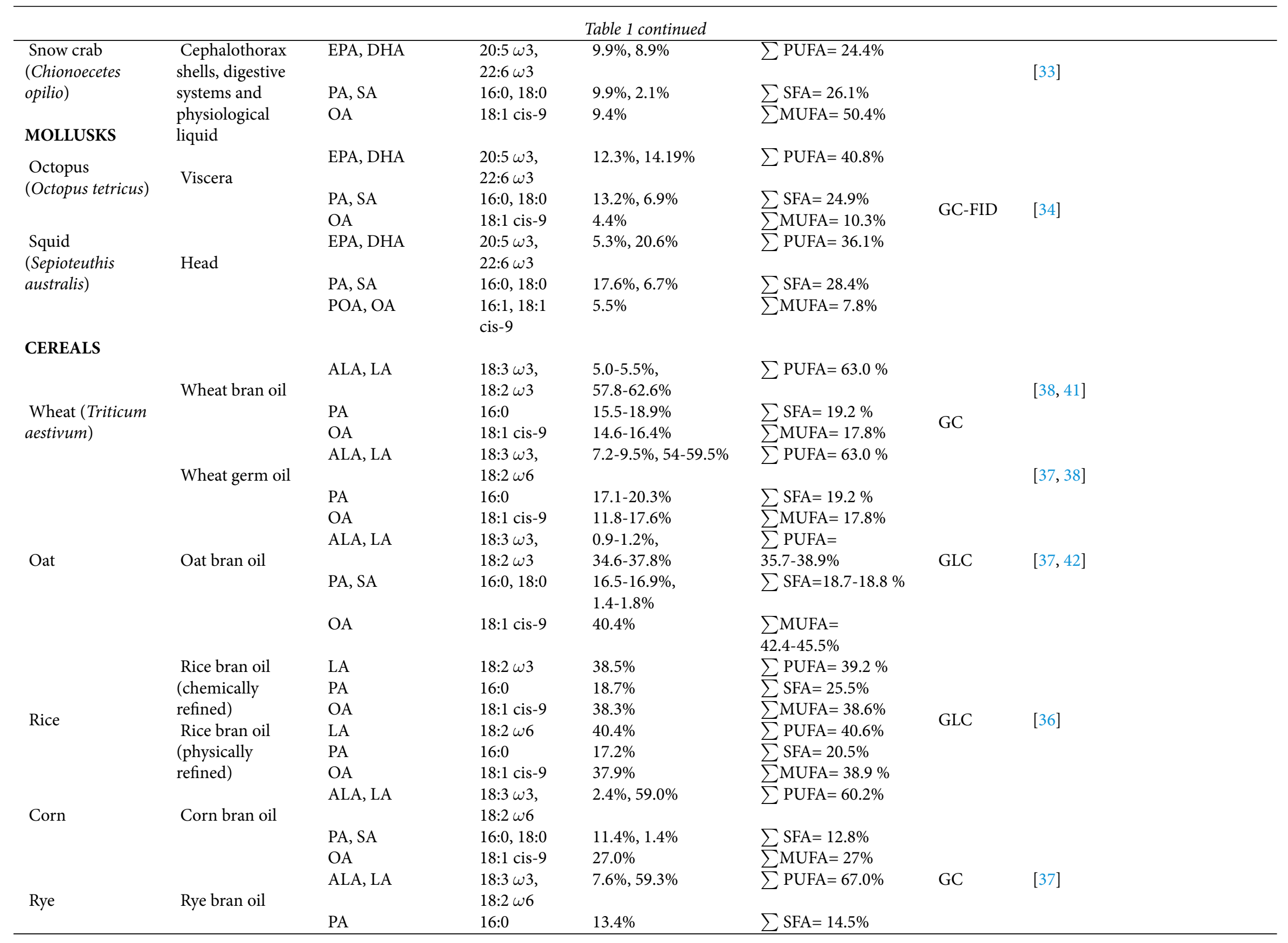




\begin{tabular}{|c|c|c|c|c|c|c|c|}
\hline \multicolumn{8}{|c|}{ Table 1 continued } \\
\hline \multirow{5}{*}{ Spelt } & \multirow{5}{*}{ Spelt bran oil } & $\mathrm{OA}$ & $18: 1$ cis-9 & $16.9 \%$ & $\sum M U F A=18.5 \%$ & \multirow{11}{*}{ GLC } & \multirow{11}{*}[43]{} \\
\hline & & ALA, LA & $18: 3 \omega 3$ & $3.2 \%, 57.7 \%$ & $\sum \mathrm{PUFA}=60.9 \%$ & & \\
\hline & & & $18: 2 \omega 6$ & & & & \\
\hline & & PA & $16: 0$ & $14.3 \%$ & $\sum \mathrm{SFA}=16.1 \%$ & & \\
\hline & & OA & $18: 1$ cis -9 & $22.0 \%$ & $\sum$ MUFA $=22.3 \%$ & & \\
\hline \multirow{6}{*}{$\begin{array}{l}\text { Sesame } \\
\text { (Sesamum } \\
\text { indicum) }\end{array}$} & \multirow{6}{*}{$\begin{array}{l}\text { White sesame } \\
\text { seed (after } \\
\text { dehulling) } \\
\text { White sesame } \\
\text { seed (after } \\
\text { hulling) }\end{array}$} & LA & $18: 2 \omega 6$ & $36.1 \%$ & $\sum \mathrm{PUFA}=36.6 \%$ & & \\
\hline & & $\mathrm{PA}, \mathrm{SA}$ & $16: 0,18: 0$ & $10.9 \%, 6.9 \%$ & $\sum \mathrm{SFA}=18.9 \%$ & & \\
\hline & & $\mathrm{OA}$ & $18: 1$ cis- 9 & $43.2 \%$ & $\sum$ MUFA $=44.6 \%$ & & \\
\hline & & LA & $18: 2 \omega 6$ & $35.6 \%$ & $\sum \mathrm{PUFA}=36.1 \%$ & & \\
\hline & & $\mathrm{PA}, \mathrm{SA}$ & $16: 0,18: 0$ & $11.4 \%, 6.9 \%$ & $\sum \mathrm{SFA}=19.4 \%$ & & \\
\hline & & $\mathrm{OA}$ & $18: 1$ cis- 9 & $43.1 \%$ & $\sum M U F A=44.5 \%$ & & \\
\hline \multicolumn{8}{|c|}{ FRUITS AND VEGETABLES } \\
\hline \multirow{3}{*}{$\begin{array}{l}\text { Quince (Cydonia } \\
\text { vulgaris) }\end{array}$} & \multirow{7}{*}{ Quince seed oil } & LA & $18: 2 \omega 6$ & $55.7 \%$ & $\sum \mathrm{PUFA}=56.2 \%$ & \multirow{4}{*}{ GC } & \multirow{3}{*}[44]{} \\
\hline & & $\mathrm{PA}$ & $16: 0$ & $6.8 \%$ & $\sum \mathrm{SFA}=8.3 \%$ & & \\
\hline & & $\mathrm{OA}$ & $18: 1$ cis -9 & $34.0 \%$ & $\sum$ MUFA $=35.5 \%$ & & \\
\hline Japanese quince & & LA & $18: 2 \omega 6$ & $52.4 \%$ & $\sum \mathrm{PUFA}=53.3 \%$ & & \multirow{4}{*}[45]{} \\
\hline (Chaenomeles & & $\mathrm{PA}$ & $16: 0$ & $9.5 \%$ & $\sum \mathrm{SFA}=11.8 \%$ & \multirow[t]{2}{*}{ GC-FID } & \\
\hline \multirow[t]{2}{*}{ japonica) } & & OA & $18: 1$ cis- 9 & $33.8 \%$ & $\sum$ MUFA $=34.9 \%$ & & \\
\hline & & LA & $18: 2 \omega 6$ & $29.3 \%$ & $\sum \mathrm{PUFA}=30.6 \%$ & \multirow{3}{*}{ GC } & \\
\hline Peanut & Peanut seed oil & $\mathrm{PA}, \mathrm{SA}$ & $16: 0,18: 0$ & $9.9 \%, 3.3 \%$ & $\sum \mathrm{SFA}=13.2 \%$ & & \multirow[t]{2}{*}[44]{} \\
\hline & & $\mathrm{OA}$ & $18: 1$ cis -9 & $54.4 \%$ & $\sum$ MUFA $=56.2 \%$ & & \\
\hline \multirow{3}{*}{$\begin{array}{l}\text { Grape (Vitis } \\
\text { vinifera) }\end{array}$} & \multirow{3}{*}{ Grape seed oil } & LA & $18: 2 \omega 6$ & $74.2 \%$ & $\sum \mathrm{PUFA}=74.3 \%$ & \multirow{4}{*}{-} & \multirow{4}{*}{ [46] } \\
\hline & & $\mathrm{PA}, \mathrm{SA}$ & $16: 0,18: 0$ & $6.7 \%, 3.8 \%$ & $\sum \mathrm{SFA}=10.6 \%$ & & \\
\hline & & $\mathrm{OA}$ & $18: 1$ cis- 9 & $14.8 \%$ & $\sum$ MUFA $=14.9 \%$ & & \\
\hline \multirow{3}{*}{ Pear (Pyrus sp.) } & \multirow{3}{*}{ Pear seed oil } & LA & $18: 2 \omega 6$ & $54.0 \%$ & $\sum \mathrm{PUFA}=54.8 \%$ & & \\
\hline & & $\mathrm{PA}, \mathrm{SA}$ & $16: 0,18: 0$ & $9.1 \%, 2.1 \%$ & $\sum \mathrm{SFA}=11.2 \%$ & \multirow{5}{*}{ GC } & \multirow{5}{*}[44]{} \\
\hline & & OA & $18: 1$ cis -9 & $32.1 \%$ & $\sum$ MUFA $=34.0 \%$ & & \\
\hline \multirow{3}{*}{$\begin{array}{l}\text { Apple (Malus } \\
\text { communis) }\end{array}$} & & LA & $18: 2 \omega 6$ & $50.3 \%$ & $\sum \mathrm{PUFA}=51.2 \%$ & & \\
\hline & Apple seed oil & $\mathrm{PA}, \mathrm{SA}$ & $16: 0,18: 0$ & $6.9 \%, 2.0 \%$ & $\sum \mathrm{SFA}=8.9 \%$ & & \\
\hline & & $\mathrm{OA}$ & $18: 1$ cis -9 & $38.3 \%$ & $\sum$ MUFA $=40.2 \%$ & & \\
\hline Tomato & & LA & $18: 2 \omega 6$ & $40.2 \%$ & $\sum \mathrm{PUFA}=40.6 \%$ & & \\
\hline (Solanum & Tomato seed & $\mathrm{PA}$ & $16: 0$ & $20.2 \%$ & $\sum \mathrm{SFA}=30.4 \%$ & GC & {$[47]$} \\
\hline lycopersicum) & & OA & $18: 1$ cis- 9 & $24 \%$ & $\sum$ MUFA $=33 \%$ & & \\
\hline & & LA & $18: 2 \omega 6$ & $17.2 \%$ & $\sum \mathrm{PUFA}=17.4 \%$ & & \\
\hline & Olive seed & $\mathrm{PA}$ & $16: 0$ & $17.6 \%$ & $\sum \mathrm{SFA}=28.7$ & & \\
\hline Olive (Olea & (Green) & OA & $18: 1$ cis -9 & $53.6 \%$ & $\sum$ MUFA $=53.9 \%$ & & \\
\hline europaea) & & LA & $18: 2 \omega 6$ & $17.2 \%$ & $\sum \mathrm{PUFA}=17.3 \%$ & GC-MS & [48] \\
\hline & Olive seed (Ride) & $\mathrm{PA}$ & $16: 0$ & $16.0 \%$ & $\sum \mathrm{SFA}=23.4 \%$ & & \\
\hline
\end{tabular}


Abbreviations : GC: gas chromatography, MS: mass spectrometry, PUFA: polyunsaturated fatty acids, MUFA: monounsaturated fatty acids, SFA: saturated fatty acids, EPA: eicosapentaenoic acid, DHA: docosahexaenoic acid, DPA: docosapentaenoic acid, PA: palmitic acid, SA: stearic acid, OA: oleic acid, ALA: $\alpha$-linolenic acid, LA: linoleic acid, n.a: not analyzed. 


\begin{tabular}{|c|c|c|c|c|c|}
\hline Extraction Method & Conditions & By-product & Product & Lipid obtained & Ref. \\
\hline Bligh \& Dyer & $\begin{array}{l}\mathrm{CHCl}_{3}: \mathrm{MeOH} \\
1: 2, \mathrm{v} / \mathrm{v}, 2 \mathrm{~min}\end{array}$ & Offal & $\begin{array}{l}\text { Rainbow trout } \\
\text { (Oncorhynchus mykiss) }\end{array}$ & $\begin{array}{l}\text { ALA, SDA ETA, EPA, DPA, } \\
\text { DHA }\end{array}$ & [49] \\
\hline Bligh \& Dyer & $\begin{array}{l}\mathrm{CHCl}_{3}: \mathrm{MeOH} \\
1: 2, \mathrm{v} / \mathrm{v}, 2 \mathrm{~min}\end{array}$ & Liver & $\begin{array}{l}\text { Balistid fish (Sufflamen } \\
\text { capistratus) }\end{array}$ & ALA, DHA, DPA, EPA & {$[50]$} \\
\hline Bligh \& Dyer & $\begin{array}{l}\mathrm{CHCl}_{3}: \mathrm{MeOH} \\
2: 1, \mathrm{v} / \mathrm{v}, 10 \mathrm{~min}\end{array}$ & Tissues & Sardinella longiceps & ALA, DHA, DPA, EPA & {$[51]$} \\
\hline Bligh \& Dyer & $\begin{array}{l}\mathrm{CHCl}_{3}: \mathrm{MeOH} \\
1: 2, \mathrm{v} / \mathrm{v}, 2 \mathrm{~min}\end{array}$ & Head, intestine and liver & Sardinella lemuru & DHA, DPA, EPA & {$[52]$} \\
\hline SxE & $\begin{array}{l}\text { n-hexane, } 80^{\circ} \mathrm{C}, 8 \\
\mathrm{~h}\end{array}$ & Seeds & Chia (Salvia hispanica L.) & ALA & {$[53]$} \\
\hline Folch // SxE & $\begin{array}{l}\mathrm{CHCl}_{3}: \mathrm{MeOH} \\
2: 1, \mathrm{v} / \mathrm{v}, 20 \mathrm{~min} / / \\
\text { n-hexane, } 4 \mathrm{~h}\end{array}$ & Guts & $\begin{array}{l}\text { Salmon (Salmo salar), red } \\
\text { coastal eel (Genipterus } \\
\text { chilensis) and yellowtail } \\
\text { horse mackerel (Seriola } \\
\text { lalandi) }\end{array}$ & ALA, DHA, DPA, EPA, ETA & [54] \\
\hline MAE & $\begin{array}{l}100-40 \% \text { of } 1,000 \\
W, 20-80 s\end{array}$ & Liver & Catfish & EPA, DHA & {$[55,56]$} \\
\hline MAE & $400 \mathrm{~W}, 120 \mathrm{~s}$ & Seeds & $\begin{array}{l}\text { Purslane (Portulaca } \\
\text { oleracea) }\end{array}$ & ALA & {$[57]$} \\
\hline MAE-SxE & $\begin{array}{l}720 \mathrm{~W}, 13 \mathrm{~min}, \\
\text { n-hexane }\end{array}$ & ns & Olives Aglandau & ALA & {$[58]$} \\
\hline UAE & $\begin{array}{l}\mathrm{C}_{4} \mathrm{H}_{8} \mathrm{O}_{2}, 176 \mathrm{~W} \\
40 \mathrm{kHz}, 20-60 \\
\min , 40-60^{\circ} \mathrm{C}\end{array}$ & Seeds & Chia (Salvia hispanica L.) & ALA & [59] \\
\hline UAE & $\begin{array}{l}\text { n-hexane, } 250 \mathrm{~W}, \\
20 \mathrm{kHz}, \mathrm{S} / \mathrm{L} 1: 10, \\
25^{\circ} \mathrm{C}\end{array}$ & Seeds & $\begin{array}{l}\text { Flaxseed (Linum } \\
\text { usitatissimum L.) }\end{array}$ & ALA & {$[60]$} \\
\hline $\mathrm{UAE}+\mathrm{EAE}$ & $\begin{array}{l}250 \mathrm{~W}, 20 \mathrm{kHz} \\
45^{\circ} \mathrm{C}, 30 \mathrm{~min}\end{array}$ & Seeds & $\begin{array}{l}\text { Flaxseed (Linum } \\
\text { usitatissimum L.) }\end{array}$ & ALA & {$[61]$} \\
\hline $\mathrm{UAE} / / \mathrm{SxE}$ & $\begin{array}{l}\text { n-hexane, } 600 \mathrm{~W}, \\
40.0 \mathrm{kHz}, 49^{\circ} \mathrm{C}, 44 \\
\mathrm{~min} / / 8 \mathrm{~h}\end{array}$ & Seeds & Seeds of I. indigotica & ALA & {$[62]$} \\
\hline $\mathrm{UAE}+\mathrm{SxE}$ & $\begin{array}{l}\text { n-hexane, } 65 \mathrm{~W}, \\
9.0 \mathrm{kHz}, 45^{\circ} \mathrm{C}, 30\end{array}$ & $\begin{array}{l}\text { Germ } \\
\text { ns }\end{array}$ & $\begin{array}{l}\text { Soybean } \\
\text { Seaweed }\end{array}$ & $\begin{array}{l}\text { ALA } \\
\text { SDA, ETA, EPA, DPA, DHA }\end{array}$ & {$[63]$} \\
\hline $\mathrm{UAE}+\mathrm{SxE}$ & $\begin{array}{l}\text { mhmexane, } 20 \mathrm{kHz} \\
50-150 \mathrm{~W}, 30 \mathrm{~min} \\
+70^{\circ} \mathrm{C}, 6 \mathrm{~h}\end{array}$ & Seeds & Grape (Vitis vinifera) & ALA & [64] \\
\hline
\end{tabular}




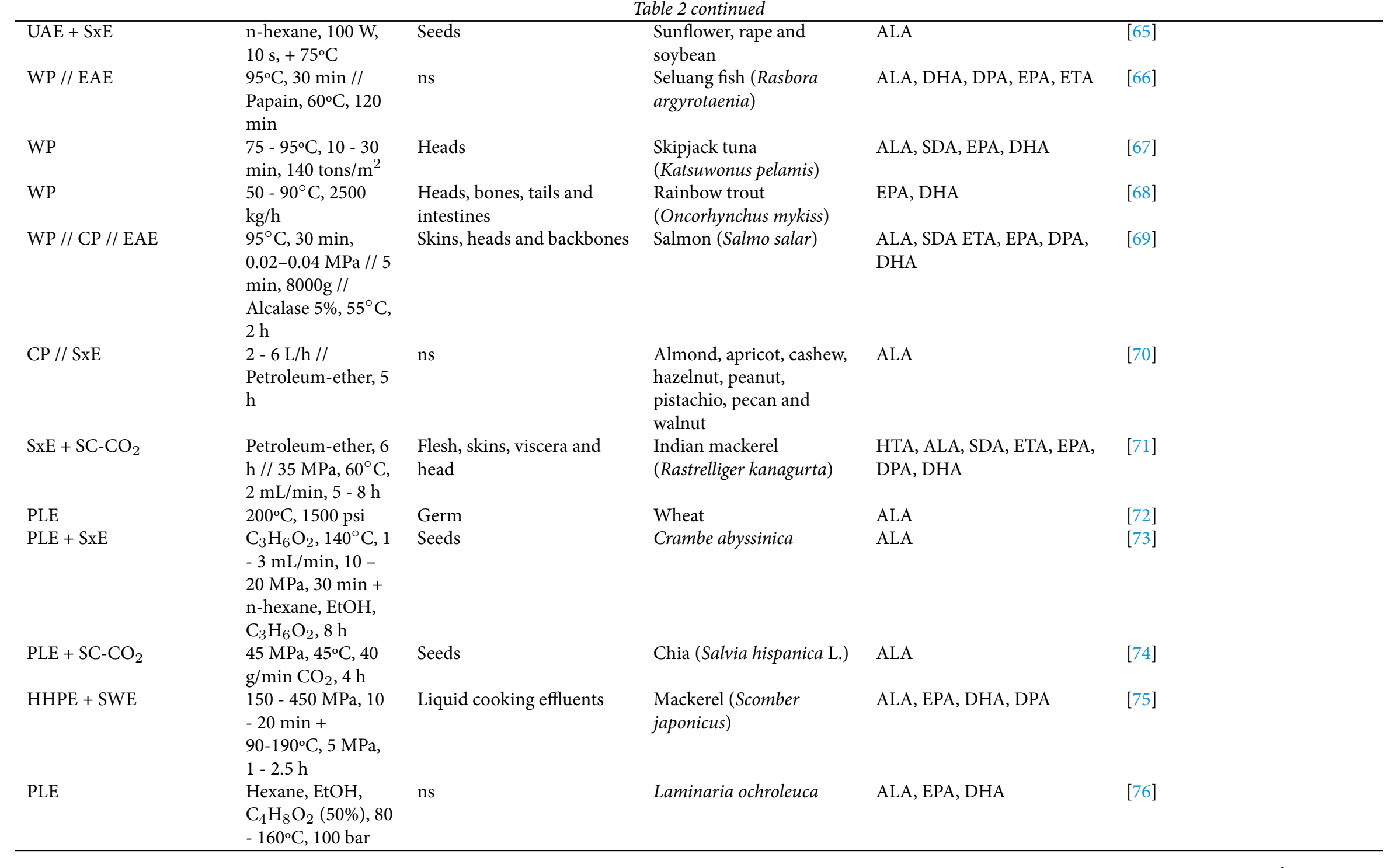




\begin{tabular}{|c|c|c|c|c|c|}
\hline $\begin{array}{l}\text { SxE // PLE // MAE // } \\
\text { UAE }\end{array}$ & $\begin{array}{l}\text { Hexane, } 8 \mathrm{~h} / / \\
\text { Hexane, EtOH, } \\
\mathrm{C}_{4} \mathrm{H}_{8} \mathrm{O}_{2}, \mathrm{~W}, 60- \\
200^{\circ} \mathrm{C}, 10 \mathrm{~min} / / \\
270-900 \mathrm{~W}, 1-2 \\
\min / / 30-80^{\circ} \mathrm{C}, \\
37 \mathrm{kHz}, 15-30 \\
\min \end{array}$ & Seeds & Echium plantagineum & ALA, SDA & [77] \\
\hline $\mathrm{SC}-\mathrm{CO}_{2} / / \mathrm{PLE}$ & $\begin{array}{l}70^{\circ} \mathrm{C}, 210 \mathrm{~min}, 45 \\
\mathrm{MPa}, 2 \mathrm{~L} / \mathrm{min} / / \\
\text { Acetone, EtOH, W, } \\
10.3 \mathrm{MPa}, 70- \\
120^{\circ} \mathrm{C}, 15 \mathrm{~min}\end{array}$ & ns & $\begin{array}{l}\text { Algerian Thymus } \\
\text { munbyanus }\end{array}$ & ALA & [78] \\
\hline $\begin{array}{l}\mathrm{SC}-\mathrm{CO}_{2} / / \text { Randall } \\
\text { extraction }\end{array}$ & $\begin{array}{l}500 \text { bar, } 60^{\circ} \mathrm{C}, 10 \\
\mathrm{~g} / \mathrm{min} / / \mathrm{n} \text {-hexane, } \\
69^{\circ} \mathrm{C}, 1 \mathrm{~h}\end{array}$ & Heads, spines and viscera & $\begin{array}{l}\text { Trout (Oncorhynchus } \\
\text { mykiss) }\end{array}$ & ALA, EPA, DHA, DPA, HTA & {$[22]$} \\
\hline SFE & $\begin{array}{l}3.5 \mathrm{~L} / \mathrm{min}, 316 \mathrm{bar} \\
10 \mathrm{~min}\end{array}$ & ns & Sturgeon & ALA, DHA, EPA, DPA & {$[79]$} \\
\hline SFE, CP, WP, EAE & $\begin{array}{l}25 \mathrm{MPa}, 40^{\circ} \mathrm{C} / / \\
\text { All: RT, } 12 \mathrm{~h} \text {; EAE: } \\
\text { Alcalase, } 0.05 \mathrm{w} / \mathrm{w} \\
\text { protein }\end{array}$ & ns & $\begin{array}{l}\text { Merluccius capensis, } \\
\text { Hoplostethus atlanticus, } \\
\text { Salmo salar and } \\
\text { Dosidicus gigas }\end{array}$ & ALA, DHA, EPA, DPA & {$[80]$} \\
\hline $\mathrm{SC}-\mathrm{CO}_{2}$ & $\begin{array}{l}40-60^{\circ} \mathrm{C}, 150- \\
350 \mathrm{~atm}, 0.3 \\
\mathrm{ml} / \mathrm{min}, 20 \mathrm{~min}\end{array}$ & ns & $\begin{array}{l}\text { Rainbow sardine fish } \\
\text { (Dussumieria acuta) }\end{array}$ & ALA, DHA, EPA & {$[81]$} \\
\hline $\mathrm{SC}-\mathrm{CO}_{2}$ & $\begin{array}{l}35-45^{\circ} \mathrm{C}, 150-250 \\
\text { bar, } 27.79 \mathrm{~g} / \mathrm{min}, \\
1.5 \mathrm{~h}\end{array}$ & ns & $\begin{array}{l}\text { Yellow croaker } \\
\text { (Larimichthys polyactis) } \\
\text { muscle }\end{array}$ & ALA, DHA, EPA & [82] \\
\hline $\mathrm{SC}-\mathrm{CO}_{2} / / \mathrm{SxE}$ & $\begin{array}{l}65^{\circ} \mathrm{C}, 40 \mathrm{MPa}, 3 \\
\mathrm{~mL} / \mathrm{min}, 2 \mathrm{~h} / / \\
\text { n-hexane, } 6 \mathrm{~h}\end{array}$ & Head, skin and viscera & Tuna species & SDA, EPA, DPA, DHA & [83] \\
\hline $\mathrm{SC}-\mathrm{CO}_{2}$ & $\begin{array}{l}40-80^{\circ} \mathrm{C}, 400 \mathrm{bar}, \\
10 \mathrm{~kg} / \mathrm{h}\end{array}$ & Seeds & Cannabis sativa $\mathrm{L}$. & ALA & {$[84]$} \\
\hline $\mathrm{SC}-\mathrm{CO}_{2}$ & $\begin{array}{l}40-80^{\circ} \mathrm{C}, 136- \\
408 \mathrm{bar}, 1.8 \mathrm{~g} / \mathrm{min}, \\
10 \mathrm{~min}\end{array}$ & Seeds & Chia (Salvia hispanica L.) & ALA & {$[85]$} \\
\hline $\mathrm{SC}-\mathrm{CO}_{2}$ & $\begin{array}{l}50^{\circ} \mathrm{C}, 30 \mathrm{MPa}, 40 \\
\mathrm{~g} / \mathrm{min}, 3 \mathrm{~h}\end{array}$ & Grain & Wheat grain & ALA & {$[86]$} \\
\hline
\end{tabular}


The highest content of LA was found for wheat bran oil, representing the $60 \%$ of total FA and until $99.4 \%$ of total PUFA $[38,41]$ (Table 1 ). $\mathrm{OA}$ is also an important MUFA found in bran oils, besides, their concentration is about two times higher that of PA (except in wheat bran oil, which present similar results). The highest content of OA was reported in oat bran oil, reaching a $40.4 \%$ of total FA content [37, 42].

Regarding ALA and SA, generally, these compounds are present in very low concentrations $(<2 \%)$ in bran oils of most cereals. However, significant concentrations of the $\omega 3$ ALA until $9.5 \%$ are found in wheat bran oil $[38,41]$ and in rye bran oil (7.6\%) [37], while SA represented until $7 \%$ of total FA in white sesame seed oil [43] (Table 1). Another by-product from cereal production evaluated in some studies are seeds. For example, Elleuch and coworkers analyzed the FA profile of sesame seed oil after de-hulling and hulling and they reported high amounts of LA and OA (all above $30 \%$ of total FA). On the contrary, lower content of SFA was observed, with values of ALA and SA under $12 \%$ in both matrix [43] (Table 1).

\subsection{Fruits and vegetables by-products}

According to FAO, UE is a major producer of vegetables and fruits. To cite some examples, 10.3 million of tons of tomatoes were produced in 2018 and 1.6 million of tons of olive oil are produced every year [35]. Parallel to this production, enormous amounts of fruits and vegetables wastes are generated and more than $20 \%$ of the global production of fruits and vegetables is lost between harvest and distribution [35]. In addition, fruit and vegetable processing industry is recognized as one of the greatest producers of food by-products, reaching to discard between 15 and $60 \%$ of the total mass of the food. To reduce waste quantities and economic costs of this industry, different by-products like peels, skin, pomace or seeds have been evaluated for the recovery of diverse compounds, including FA. In this sense, most studies have used fruits and vegetable seeds to obtain FA [19, 47, 87]. In Table 1, the FA composition of different fruit and vegetable seeds has been compiled. According to these data, their FA profiles are very similar, highlighting the PUFA and MUFA fractions.

In these fractions, LA and OA are the most predominant FA, respectively, with percentages that vary between $17-74 \%$ for LA and between $14-60 \%$ for OA. Considering the compiled data, high amounts of LA are present in quince and grape seeds, with values of $55.7 \%$ and $74.2 \%$ of the total PUFA, respectively [44, 46]. On the other hand, large amounts of OA are found in olive seed ride and peanut seeds oil, corresponding to a $54.4 \%$ and $59.1 \%$, respectively [44, 48] (Table 1). In addition, most studies found that about $98 \%$ of total PUFA and about $95 \%$ of total MUFA correspond to LA and OA, respectively. However, a study shows that the highest OA proportion for tomato seed oil was $72 \%$ of total MUFA [47]. Finally, the main SFA are PA and SA, which are present in low concentrations in the studied matrix, both in proportions below $10 \%$, except in tomato and olive by-products, in which the percentage of PA varies between 16\%-20\% (Table 1). Generally, the proportions of PA and SA were very similar for all vegetable and fruits seed oils, with variations between $6-9 \%$ for PA, and $2-4 \%$ for SA. However, other studies found that PA in tomato and olive seed oils reached up to $17 \%$ and $20 \%$ of total FAs, respectively $[47,48]$ (Table 1).

\section{TRADITIONAL AND EMERGING EXTRACTION TECHNOLOGIES OF OMEGA-3 FATTY ACIDS}

The most common lipid extraction methods traditionally used from food-related matrix are solvent extraction (SE), Soxhlet extraction (SxE), Wet Pressing (WP) and Cold Pressing (CP) [88, 89]. At present, it is pursued the development of environmentally friendly extraction techniques since the sustainability of the processes to recover bioactive compounds is of the utmost importance [90]. Following this trend, some modern or greener extraction methods have emerged, including microwave-assisted extraction (MAE), ultrasound-assisted extraction (UAE), pressurized liquid extraction (PLE) and supercritical fluid extraction (SFE) [91]. In general, these techniques have some important advantages, such as lower organic solvent consumption, shorter extraction time and greater selectivity, as well as great versatility and efficiency [92]. The main conventional and non-conventional methods for the recovery of oils rich in $\omega 3 \mathrm{FA}$ are shown in Table 2 and represented in Figure 2.

\subsection{Conventional extraction methods}

\subsubsection{Solvent extraction}

Solvent extraction (SE) can be considered the most common extraction method nowadays used for recovering lipids from different food matrices such as fruits, vegetable oils, seeds, nuts, animal fats, and fish oils [93]. Both Folch [94] and Bligh \& Dyer methods [95] are the most widely used SE resulting in yields higher than 95\% [96]. The Folch method is performed by a mixture of chloroform and methanol $(2: 1, \mathrm{v} / \mathrm{v})$ and is based on the solubility of lipids in organic solvents and their insolubility in water, allowing them to be separated into insoluble (lipids) and soluble (proteins, carbohydrates and minerals) components [97]. On the other hand, the Bligh and Dyer methodology applies a mixture of chloroform: methanol: water $(2: 2: 1.8, \mathrm{v} / \mathrm{v})$ in a two-step extraction protocol [95, 98]. In terms of applicability, Folch method can be used to extract lipids from most foods matrix, whereas the Bligh \& Dyer procedure, initially developed using cod muscle, can be now applied to any tissue containing $80 \%$ water (e.g. tissues of vascular plants) [93]. Recently, it has been reported that a single FA extraction using a chromatographic column with chloroform, methanol and water, is a solid, easy and cost efficient alternative to Folch method for salmon and chicken samples analyses avoiding centrifugation and pipetting steps [99]. However, the large amounts of residual toxic solvents (chloroform and methanol) are of supreme concern for the health and safety of chemical sector workers and for the environment [100, 101]. In addition these techniques entail other limitations like the time and energy consumption $[75,96]$. Thus, SE is nowadays used for analytical purposes but not for industrial production, due to restrictions in the food industry. To overcome the toxicity of chloroform, alternative solvent systems have been developed with hexane, ethyl acetate and isopropanol, however these are usually less efficient [93]. 


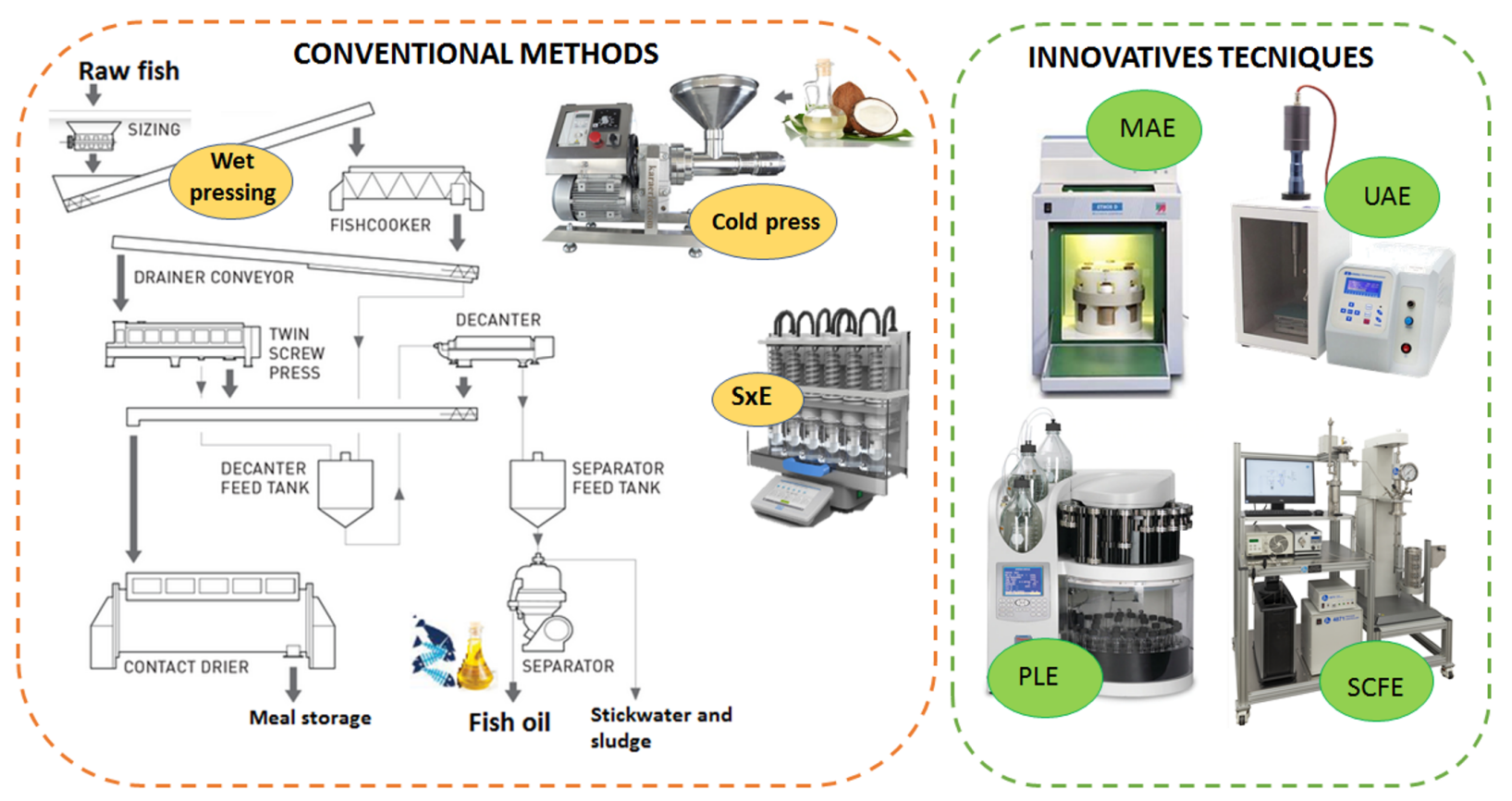

Figure 2 Traditional extraction of oil versus innovative techniques.

\subsubsection{Soxhlet extraction}

Soxhlet extraction ( $\mathrm{SxE}$ ) is a conventional technique used for the recovery of lipids from food employing organic solvents such as hexane and petroleum ether. In fact, Soxhlet set-up is the commercial extraction method of Palm-pressed Mesocarp Oil employing hexane. It has been used in palm oil mills in a solvent reflux system that continuously extracts the oil for 4-6 h [102]. Sahena and co-workers employed petroleum ether in a $6 \mathrm{~h}$ process to obtain ALA, EPA, DPA and DHA, from flesh, skins, viscera and head of mackerel Rastrelliger kanagurta [71]. Also, SxE using petroleum ether ( $5 \mathrm{~h}$ process) was applied to almond, apricot, cashew, hazelnut, peanut, pistachio, pecan and walnut to obtain ALA [70]. SxE procedure is very simple, When the powdered solid sample is placed in the cartridge of porous material in the Soxhlet extractor chamber, flask is heated. Then, the solvent evaporates and moves up to the condenser extracting the fats and carries them into the flask [91, 103]. Despite its simplicity, it has some disadvantages: long extraction times, large quantities of extraction residues, flammable organic solvents and the possibility of thermal decomposition of thermolabile compounds due to the high temperatures generated during the process [93, 103]. Thus, several modifications to the process have been developed to improve its efficiency and automation [104]. With the application of auxiliary energies such as UAE or MAE, the efficiency of this technique has been increased [4]

\subsubsection{Wet pressing}

Wet pressing (WP) is the most widely used method for fish oil production at industrial scale. It is basically carried out in four steps: fish cooking $\left(85-95^{\circ} \mathrm{C}\right)$, pressing the cooked matrix, decantation and centrifugation to recover the oil [66]. Subsequently, to produce edible oils, fish oil undergoes a refining process to remove impurities, such as non-triglyceric compounds, dyes, odorous and toxic compounds. Several European companies, mainly in Iceland, Norway, Denmark and Spain, produce fish oil using WP [101]. This traditional process of obtaining fish oil yields good results by using fish products or their by-products with a high oil content, such as herring, tuna, sardine, and salmon. However, it is not as feasible when the oil content is low [101]. And this technique is often used for fish oil extraction processes, even though it is not always the optimal choice [66]. In addition, WP has other several drawbacks. It involves the use of chemicals that pollute the environment and some neutral oil is lost [101, 105]. WP is an energy-intensive process [105] and the hight temperature and pressure conditions used for protein coagulation and further oil release may partially modify the PUFAs content due to the hydrolysis and oxidation reactions [97].

\subsubsection{Cold pressing}

Cold pressing (CP) extraction is a type of mechanical press method which is carried out at low temperature (below $50{ }^{\circ} \mathrm{C}$ ) and pressure [106]. It is used to extract oil from a range of matrices like soybean, rapeseed, corn, grapeseed, hemp, flaxseed, rice bran, olive, nut, wheat and pumpkin $[88,107]$, but is especially used in oil production from oilseeds. CP is often used in rural areas due to the low initial investment cost and the non-requirement of highly trained personnel to operate the machines. CP can be an economical method as it not only excludes the use of heat but also organic solvent. However, one of the disadvantages of this technique is low yields obtained. For example, yields of Virgin Coconut Oil obtained by CP are about 46-49\% [102] . Another disadvantage of this technique is the difficulty to obtain a highly quality product [88]. A study showed the amount and the characteristics of the oil extracted from salmon by-products which resulted in high content of $\omega 3 \mathrm{FA}, \mathrm{EPA}$ and DHA $(22: 6 \omega 3)$ but with yields of 8.60- 
$21.00 \%$ [108]. Although extraction methods especially for the more conventional oilseeds are known, there has been a continuous quest by researchers to improve extraction yields.

\subsection{Innovative extraction methods}

\subsubsection{Microwave-assisted extraction}

Microwave assisted extraction (MAE) is one of the most novel and attractive alternative oil extraction methods. It combines solvent extraction with microwave heating power, so that heated solvent gets in contact with the solid matrix to extract the compounds of interest from sample solution [92]. In recent years, there has been an increase in reports of rapid and high-quality MAE extraction of oilseeds [59, 109], fish by-products [55, 56], yeasts [110] and microalgae $[63,111]$. For example, it was feasible to obtain oil rich in EPA and DHA from liver of catfish and oil rich in ALA from seeds of purslane and Olive aglandau $[57,58]$. MAE consumes a minimum amount of solvent, energy and time due to the rapid and homogeneous heating of the solvent, the generation of high pressure leading to cell rupture and the release of active components from broken cells [112, 113]. Many factors influence the extraction efficiency such as particle size, solvent, time, and microwave frequency [92]. MAE is highly selective, depending largely on the nature of the solvent and the matrix (Castejón et al., 2018) so that it is suitable for oil extraction when employing the proper combinations of solvent. Generally, water is not used while hexane is combined with other different solvents, leading to the extraction of polar and non-polar FAs [100]. However, it has been reported a low MAE efficiency when target compounds or solvents are non-polar, or when they are volatile [78].

\subsubsection{Ultrasound-assisted extraction}

Ultrasound-assisted extraction (UAE) has been widely applied by food, nutritional and pharmaceutical industries to obtain bioactive FA. UAE requires small amount of solvent and energy and the temperature and extraction time are significatively reduced compared other conventional methods [114]. UAE is based on high-energy ultrasound waves passing through the liquids and creating high/low-pressure cycles, resulting in the phenomenon of acoustic cavitation that leads to cell rupture, intensifying solvent penetration and improving mass transfer between the intercellular materials and the solvent $[91,115,116]$. UAE has been applied for oil extraction from seeds (Castejón et al., 2018; ; VillanuevaBermejo et al., 2019) [59] and microalgae [4]. In papaya and flax seeds, it was used with hexane to obtain oil suitable for dietary oil products rich in OA and ALA, respectively [60, 117]. However, it is barely employed for the extraction of fish oil [92]. This technique can also be used as pre-treatment before the main extraction process. A recent study shows UAE as a pre-treatment to remove mucilage from chia seeds, which are usually difficult to extract using polar solvents [118]. UAE was combined with other techniques to increase FA extraction efficiency. For example, an aqueous enzymatic process assisted by UAE was applied to the extraction of linseed oil (Linum usitatissimum L.), for obtaining an oil richer in PUFAs than that obtained using the conventional solvent extraction method [61]. Also, the combination of UAE with MAE for the extraction of DHA-rich oils from microalgae has been studied, concluding that both technologies used alone or in combination could reduce costs and improve the rate of extraction and yield compared to conventional extraction [63, 119].

\subsubsection{Pressurized liquid extraction}

Pressurized liquid extraction (PLE) has already been explored as the extraction technique for a variety of bioactive compounds from food-related by-products, from agricultural and food industry sources, mostly focused on vegetal products [90]. PLE uses solvents at high temperatures and pressures, always below their respective critical points, so that the liquid state of the solvent is maintained throughout the extraction process [90, 120, 121]. Due to these pressure and temperature conditions, the surface tension of the solvent are reduced while the solubility of the analytes increases, allowing a easier solvent penetration and resulting a in faster extraction processes while requiring small amounts of solvents [121, 122]. Besides, PLE is a versatile technique since high range of solvents that can be used, including ethanol, ethyl acetate, ethyl lactate, D-limonene or hexane. When involves the use of water as solvent, technique is called subcritical water extraction (SWE) (Castejón et al., 2018). For the extraction of facts, low- or mediumpolarity solvents such as hexane, D-limonene, ethyl acetate, methyl acetate or ethanol are generally used at temperature ranges from 90 to $220^{\circ} \mathrm{C}$ [122-124]. PLE applied for FAs extraction from Laminaria ochroleuca using hexane, ethyl acetate, ethanol, and ethanol/water (1:1) showed that both ethyl acetate and ethanol enriched USFA in the lipid fraction of L. ochroleuca, providing extracts up to 55\% of their total FA content compared to other solvents [76]. Different PLE extraction conditions of $\omega 3$-rich oil from Echium plantagineum L. seeds were recently evaluated, allowing to obtain similar oil yield $(31.2 \%)$ to $\mathrm{SxE}$ (hexane, $8 \mathrm{~h}$ ) at optimum PLE conditions $\left(150^{\circ} \mathrm{C}\right.$ ethanol, $10 \mathrm{~min}$ ) and higher yields compared to MAE (21.2\%) and UAE (29.1\%) (Castejón et al., 2018). Similarly, a study examined the PLE of wheat germ oil showing a decreased in the solvent consumption and extraction time compared to the SxE while the $\omega 3$ and $\omega 6$ FA composition of the extracts was not affected by either temperature or extraction method [72].

\subsubsection{Supercritical fluid extraction}

Supercritical fluid extraction (SFE) has attracted interest for developing lipid extraction protocols, both for analytical and industrial applications [4]. Supercritical status is achieved when the temperature and pressure of a substance rise above its critical value, and fluid behave as a hybrid between a liquid and a gas [90]. Supercritical fluids show better mass transfer than liquids, due to their low viscosity and higher diffusivity properties, reducing the extraction time and providing higher extraction yields [97, 116]. Another major advantage of SFE is the reduced use of organic solvents (zero in many cases) allowing the use of nontoxic solvents, such as carbon dioxide $\left(\mathrm{CO}_{2}\right)$. In fact, it is the most commonly used extraction solvent $\left(\mathrm{SC}-\mathrm{CO}_{2}\right)[122,125] \cdot \mathrm{CO}_{2}$ has easily achievable critical conditions $\left(30.9^{\circ} \mathrm{C}\right.$ and $\left.73.8 \mathrm{bar}\right)$, is easily separable from the solute, does not cause environmental problems; is non-flammable, non-toxic and inexpensive [126]. Its main limitations are the separation of polar compounds, and its high requirements in terms of expensive equipment and energy 
consumption to achieve supercritical pressures (Taher et al., 2020; ) [127]. SC- $\mathrm{CO}_{2}$ has been established as an alternative to solvent extraction for lipids, for example, for the extraction of PUFAs from fish and vegetable oils [84]. Since $\mathrm{CO}_{2}$ is non-polar, less or nonpolar isomers forms of PUFAs can be extracted more efficiently, compared to polar forms [100]. The reported $\omega 3$ PUFAs contents in the extracted oil differ depending on the FA profile of the matrix, whereas some studies show that $\omega 3$ PUFAs content is not affected by the extraction method [105].

\section{PURIFICATION METHODOLOGIES FOR OMEGA 3 FATTY ACIDS}

In recent years, purification methods have been developed to isolate or concentrate $\omega 3$ PUFAs from different oils. The first step is to convert natural triglycerides into ethyl esters (EE) or free fatty acids (FFA) with ethanol [101]. Only when EE or FFA are separated from the main glycerol chain can their concentrations be enriched [128, 129]. Current methods for $\omega 3$-FA purification include molecular distillation (MD), enzymatic enrichment, low temperature crystallization, urea precipitation, supercritical fluid chromatography (SFC) and high resolution liquid chromatography (HPLC) [101]. Applying these methods individually, it is feasible to achieve concentrations up to $30 \%$ of EPA and DHA from marine oils [130]. However, when these protocols are used together (e.g., adduction of urea followed by multiple rounds of $\mathrm{MD}$ ), the concentration of PUFAs increased up to 85\% purity [131]. Furthermore, SFE can be used as a concentration method: the higher the molecular weight of the FA, the less solubility in $\mathrm{SC}-\mathrm{CO}_{2}$. $\mathrm{SC}-\mathrm{CO}_{2}$ can also be used for the selective separation between all C18, C20 and C22 FAs [132]. Unfortunately, it has been established that the selectivity of SFE of PUFA is only based on the number of carbons of the chain, but not on the number of double bonds. SFE should therefore be combined with other techniques, such as urea complexion [133]. Currently, the purification technology used at industrial scale with the ability to provide consistently high purity EPA or DHA (>95\%) is based on liquid chromatography (LC) and SFC [131].

\subsection{Liquid Chromatography (LC)}

Liquid Chromatography (LC) is, together with SFC, the most selective separation technique, discriminating both by the length of the chain of FAs as well as by their degree of unsaturation, [130]. Several types of LC can be applied, depending on the stationary phase used: high performance liquid chromatography (HPLC), liquid-solid chromatography (LSC), liquid-liquid chromatography (LLC) and reverse-phase chromatography (RP) [134]. HPLC reach purities above $90 \%$. RP-HPLC plays a key role in the analysis of long-chain PUFAs, allowing the separation of those FAs that cannot be separated by normal phase HPLC $[135,136]$. The main drawback of HPLC is the poor resolution for complex mixtures and the low sensitivity, although this can be avoided by using mass spectrometry (MS) [137]. The application of HPLC coupled to mass spectrometry (HPLC-MS) is relatively recent, but suitable for the precise determination of PUFAs [138]. Numerous ionization and detection modes can be applied for FAs analysis such as electrospray ionization (ESI), atmospheric pressure chemical ionization (APCI), or time of flight (TOF) [138-140]. Also, the use of tandem mass spectrometry (HPLC-MS/MS) provides a more specific detection of the FAs and their derivatives, being able to determine the position of the double bonds or the ramifications in the FA chain ( ; Volpato et al., 2017) [138]. Another common method is silver ion chromatography (Ag-HPLC), which uses embedded silver ions in the stationary phase [141]. In Ag-HPLC, triacylglycerides are separated according to the number, geometric configuration and position of the double bonds, increasing the retention as the number of double bonds increases [131, 142]. At last, another disadvantage of LC is the generation of large volumes of toxic solvents that need to be removed from the isolated FA, often causing oxidative stress in PUFAs [128].

\subsubsection{Supercritical Fluid Chromatography (SFC)}

Supercritical Fluid Chromatography (SFC) uses supercritical fluids, usually $\mathrm{CO}_{2}$ as mobile phase instead of the toxic organic solvents used in LC [101, 143]. SFC is considered a hybrid of gas chromatography (GC) and HPLC, presenting many advantages over these two methods, such as high separation efficiency, low consumption of organic solvents and short separation time [144]. SCF is used at an industrial scale, allowing up to $99 \%$ of pure individual FAs. This high selectivity is achieved by the separation according to the chain length and the number of double bonds of the FAs. Due to the low viscosity of supercritical $\mathrm{CO}_{2}$, the use of long chromatographic columns filled with highly selective filler material can be employed. In addition, working temperatures between $40-50^{\circ} \mathrm{C}$ prevent thermal stress in EPA and DHA. SFC is therefore considered one of the most appropriate technologies for the concentration of $\omega 3$-FAs [128]. SFE allows the use of universal detectors such as flame ionization detectors (FID), evaporative light dispersion detectors (ELSD) or MS, providing very good sensitivity levels when combining SFE, SFC and MS [137, 139]. The SFE/SFC coupling offers the advantages of each method: SFE can selectively extract the fraction of FAs whereas SFC can eliminate any organic solvent that remains from the procedure [145].

\section{FATTY ACIDS ENCAPSULATION AND INCORPORATION IN FOODS}

Food industry has developed different encapsulation techniques using diverse shell materials which have allowed obtaining capsules with variable physical properties. This variability in the process has permitted to adequate the type of capsules for protecting a huge variability of core ingredients. Encapsulation prevents the biological and physicochemical degradation of the biocompounds and improves their chemical stability and hence protects their bioactivities. Besides, encapsulation may also allow the controlled release of very specific concentrations of the biocompounds. Scientific literature provides several examples of different FA which have been encapsulated to improve the nutritional value of food matrixes and, in some cases, to extend their shelf-life. 


\subsection{Emulsions}

Emulsions are created by the agitation of at least two immiscible liquids, such as water and oil. This mechanical process generates heterogeneous mixtures in which fine droplets of the dispersed phase are uniformly spread throughout the continuous phase. The stability of emulsions is quite low since phases can get newly separated. To improve the stability and emulsion efficiency different (co-) surfactants or emulsifying agents can be utilized. Foodgrade emulsifying agents employed in food industry for FA mainly include protein- or polysaccharide-based ingredients such as whey, gelatin, casein, lecithin, Arabic gum, chitosan, maltodextrin, or pectin $[146,147]$. Obtained droplets by emulsification can possess very variable diameters although, those created with industrial purposes usually have a range between the nano $(\mathrm{nm})$ and micro $(\mu \mathrm{m})$ scale [148]. They can be achieved by following simple steps based on stirring/sonication or by using specific techniques, such as microfluidization, that require the application of high pressure through microchannels, high-energy inputs and specific instruments but it produces ultrafine emulsions at very low surfactant-to-oil ratios [147].

Emulsions with thermal and thermodynamic stability have been proved to increase the bioavailability of the core ingredients. That is because emulsions prevent from direct exposure to chemical, enzymatic and/or physical agents, especially, during food processing. Hence, they improve not just the bioavailability, but the bioaccessibility and bioactivity of core ingredients, besides they provide a tool to control their release (Ricaurte et al., 2016, 2018). Based on these benefits, food industry has tested the performance of many core ingredients emulsified with several surfactants into different matrixes. Among the assayed food matrixes, meat and dairy products are the most usual targets (Table 3 ). The application of emulsions is mainly meant to reduce fat content, especially saturated lipids, and/or to extend their life-shelf but without altering the organoleptic properties of the product.

Several works have demonstrated the viability and benefits of replacing animal fats with vegetal ones in different meat matrixes. For instance, freeze-dried pineapple by-product and canola oil were used to replace fat content in beef burgers. This treatment was showed to improve the lipidic profile by reducing saturated fats from 31 to $27 \mathrm{~g} / 100 \mathrm{~g}$, MUFAs increased from 45 to $53 \mathrm{~g} / 100 \mathrm{~g}$ and PUFAs from 13 to $15 \mathrm{~g} / 100 \mathrm{~g}$. This alteration of the fat profile provided a reduction in the in the $\omega 6 / \omega 3$ ratio, and therefore in the atherogenic and thrombogenic indexes. Therefore, the emulsion containing a mixture of canola oil and pineapple by-product was considered a useful fat replacer capable of providing a healthier kind of burgers [149]. Salvia hispanica (chia) and Avena sativa (avena) were also used to crease emulsion gels ant to partially replace animal fat in a class of sausages named after "longaniza". The composition of cooked sausages showed a higher PUFAs content, especially in sausages incorporated with S. hispanica. In general terms, the inclusion of these vegetal-based emulsions significantly minimized the weight loss during grilling and also increased lightness, lipid oxidation and texture of sausages [150]. In beef sausages the total or partial replacement of animal fat was performed with pre-emulsified hazelnut oil and powder with no apparent sensorial alterations. This approach displayed a reduction into the content of SFA (from 47 to $14 \%$ ) accompanied of an increment of MUFAs (from 42 to $71 \%$ ) and PUFAs (from 4 to 11\%). This alteration in the lipidic profile of sausages was revealed to be healthier since it provides low indexes of atherogenicity and thrombogenicity [151]. Different emulsion gels containing different ratios of soy protein, carrageenan and inulin were also tested to replace animal fat in frankfurters. Reformulated frankfurters presented a reduction of 53\% of SFA while increased the amount of PUFAs. Again, this shift in the FA profile leads to the reduction of the atherogenicity and thrombogenicity indexes which newly indicates the health benefits that involves this fat replacement [152]. The effect of inverse emulsions of water/oil and carrot powder was assayed into beef meat batters. Their use reduced the saturated fat content from 46 to $17 \%$ with an increment in MUFAs from 51 to $72 \%$ and in PUFAs from 2 to $10 \%$. Color shifts induced by emulsions were counteracted by carrot powder that also provided antioxidant capacity [153].

Dairy products, mainly yogurts, have been also fortified using emulsioned ingredients. Nanoemulsions of sweet almond and sesame oil tested in yogurt showed to be able to decrease $\mathrm{pH}$ and syneresis degree and to increase acidity, malondialdehyde formation, and antioxidant activity. The addition of the emulsions slightly modified the yogurt viscosity and the sensory acceptability. However, they were demonstrated to reduce the content of saturated fats to half, MUFAs can be nearly doubled and PUFAs can be increased to more than 10 -folds. Therefore, these emulsions were considered positive in terms of health benefits despite the sensorial alterations they induced [154]. Phoenix dactylifera pollen grains were used to fortified yogurt by direct addition of the grains, or by the addition of a free ethanolic extract $80 \%$ or its encapsulated form. This vegetal matrix was selected for its high nutritional content (proteins, carbohydrates, and minerals) which also revealed it as a source of PUFAs and MUFAs and antioxidants (phenolic compounds, mainly catechins). These properties permitted to reduce the amount of saturated fats while increasing PUFAs and MUFAs, which prompted a slight increment in the $\omega 6 / \omega 3$-ratio. Among the three fortification strategies, the nanoencapsulated showed a more similar yoghurt microstructure to the control, it reduced syneresis and viscosity, increased the water holding capacity and did not modify the yogurt color [155]. Similar results were obtained in an experiment into which a nanoemulsion of fish oil and $\gamma$-oryzanol was added to yogurt. The nanoemulsion reduced the acidity and syneresis of yogurt and the fortification meant a huge increment of PUFAs due to the significant amount of EPA and DHA in fish oil. These $\omega 3$ PUFAs usually get easily oxidized however the use of nanoemulsion reduced the oxidative environment and showed low peroxide values. Even though, the sensorial panel and the viscosity of the final product were not as good as the plain yogurt the introduction of optimized nanoemulsions seems a promising strategy to fortify dairy products [156].

Apart from their use for fortifying food matrixes, nanoemulsions have been also included in films becoming active packaging even with biodegradable properties. The fibrous film into which nanoemulsions containing high oleic palm oil were embedded was described to be capable of extending shelf- life products and decreasing storage costs while using an innovative product with application for any lipidic product [157]. 


\subsection{Encapsulation: spray-drying}

In food industry very different strategies, with diverse complexity degrees, have been developed to encapsulate a huge variability of biocompounds [9]. FA are encapsulated with the final aim of preserving them against oxidation processes triggered by external factors such as humidity, light, or temperature [158]. Some of the most used encapsulation methods include spray or freeze drying, spray chilling and cooling, coacervation, fluidized bed coating, liposome entrapment, rotational suspension separation, extrusion and inclusion complexation, etc. [159]. Among them, the most widely applied for encapsulating FA is spray drying together with freeze drying (Table 3). However, the high-quality and high efficiency rates, its flexibility and easy handle make spray drying an economical and affordable encapsulation technique despite the high consumption of energy it requires $[158,159]$.

Very different FA have been spray-dried encapsulated and utilized for fortifying food matrixes, mainly meat, bakery and dairy products (Table 3). For instance, the oil extracted from Salvia hispanica (S. hispanica) is well known for its high content of ALA, an $\omega 3$ PUFA with beneficial health properties but with a high autooxidation ratio too. To prevent this oxidation, the obtained oil was encapsulated by spray drying using chitosan as shell material and used to fortify butter at different levels. This type of microcapsules resulting in an increment of $17 \%$ of the PUFAs content, providing high antioxidant activity that nearly reached $70 \%$ after 90 days of storage and without affecting the sensorial properties of the butter [174]. Parallelly, the oil extracted from Lepidium sativum seeds has also been demonstrated to possess high levels of ALA and it is also used for fortifying food products. One study shows the oil microencapsulation by spray drying using whey as well ingredient to fortify biscuits, resulting in a slightly reduction of ALA oxidation and an improvement of the lipidic profile of the biscuits with an acceptable organoleptic properties from a sensorial point of view [175].

In addition, different works have taken profit of the encapsulation of fish or shrimp oil to mainly fortify dairy products and meat (Table 3). For instance, three different cheese classes named after queso fresco, cheddar, and mozzarella were fortified with $\omega 3$ PUFAs obtained from flaxseed oil or fish oil. Fish oil was microencapsulated for masking its organoleptic properties but maintain its nutritional properties. The fortification of the cheddar cheese modified some physicochemical properties and textures but was the cheese class that suffered fewer alterations. Cheddar was the cheese that showed higher $\omega 3$ PUFAs retention, up to $9 \mathrm{mg} / \mathrm{g}$, and around $5 \mathrm{mg} / \mathrm{g}$ for $\omega 6$. This high retention of PUFAs means that the daily consumption of a portion of this cheese (50-100 g) can supply the recommended amount of $\omega 3$ in order to prevent the development of cardiovascular diseases. Therefore, the optimization of fish oil fortification of cheese represents a very promising strategy to provide functional properties with health benefits [176] . In other dairy products such as yogurts, micro- and nanocapsules containing fish oil seems to have neutralized fishy odors and flavors. In a study yogurt was fortified utilizing nano-liposomes to nano-encapsulate fish oil. As observed in works cited above, the inclusion of the nanocapsules reduced the acidity and syneresis but also the peroxide value along for weeks. Besides, this fortification resulted in an increment of the amount of DHA and EPA while mostly preserving the sensory properties of the yogurt fortified [177]. Similarly, in a previously published work, a strawberry yogurt was fortifies using microencapsulated salmon oil. In this case, the addition of the microcapsules did not affect to the acidity, syneresis, color or waterholding capacity. The oxidation of the yogurt, mainly triggered by its time storage, was not prevented by the fortification. However, the values of thiobarbituric acid that both samples, control and treated, reached were kept low which avoided sensorial alterations. The addition of microcapsules modified the lipidic profile of the yogurt, even after one month of storage. The amount of saturated fatty acids was reduced from 66 to $58 \%$ while MUFAs were incremented from 28 to $32 \%$ and PUFAs from 6 to $10 \%$. The improved fatty acid profile of the fortified yogurt demonstrates the benefits of using fish oil to provide more healthy options to consumers [178]. Also skim milk has been fortified with nanoliposomes loaded with shrimp oil showing no sensorial alterations related with the use of marine products. Besides the fatty acid profile of this fortified milk showed similar content of saturated and PUFAs (about $39 \mathrm{~g} / 100 \mathrm{~g}$ of lipids) and a high presence of MUFAs (20g/100g of lipids) [179].

Therefore, as demonstrated with these examples, emulsions or encapsulation represents a very useful tool for improving the nutritional value of products and represent a huge benefit to exploit the use of fish or agriculture by-products derived from marine or horticulture activities. The strong flavor and/or odor that they usually possess can be masked by their encapsulation which permits to exploit them as a sustainable source of very interesting FA.

\section{FUTURE TRENDS AND MAIN CHALLENGES}

FAs have been used in many different fields due to their potential applications, from environmental purposes to food science functions. In the food industry, FAs are mainly used as supplements since supplementing food with $\omega 3$ or its use for pharmaceutical applications are feasible options for complementing the optimum dietary intake $[2,180]$. In a similar way, other studies in animal feed opt for supplementing animals' diet to get a better FA profile [181]. Some of the most recent studies include the supplementation of Oreochromis niloticus fillets with fish oil which causes a significant reduction of $\omega 6 / \omega 3$ ratio (Duarte et al., 2021). More recently, FAs have shown their potential as coagents to treat tuberculosis in mice administrated with LA, ALA, EPA and DHA for 3 days. At the end of the treatment, the mice showed lower $\omega 6 / \omega 3$ ratio and lower levels of pro-inflammatory interleukins (IL- $1 \alpha$, IL$1 \beta$ and IL-6), thus being potentially applicable to the pharmaceutic industry [182].

By-products from the fish, crustacean, cereal and fruit and vegetable industries have been revealed as a source of high-value FAs [23, 183]. For the efficient recover of these compounds, it is essential to know the total content of FAs in these by-products as well as the perfect extraction and purification techniques aimed at optimizing their recovery. From available extraction methods, MAE and UAE are still in the process of being applied to byproducts processing [100]. On the other hand, the most recent approaches are focused on Enzyme Assisted Extraction (EAE) or $\mathrm{SC}-\mathrm{CO}_{2}$ combined with other clean fractionation techniques. EAE is and enzymatic hydrolysis method that use exogenous enzymes to makes digestion process better controllable and reproducible [92]. 
Table 3 Applications of encapsulated FAs with marine and terrestrial origin. FAs extracted from different sources and encapsulated with diverse shell materials and techniques have been applied to different kind of matrixes to improve their quality properties.

\begin{tabular}{|c|c|c|c|c|}
\hline $\begin{array}{l}\text { Fatty acid } \\
\text { source }\end{array}$ & Shell material & $\begin{array}{l}\text { Encapsulation } \\
\text { strategy }\end{array}$ & Matrix & Properties \\
\hline
\end{tabular}

\begin{tabular}{|c|c|c|c|c|}
\hline Fish oil & $\begin{array}{l}\text { Lecithin-chitosan and } \\
\text { maltodextrin }\end{array}$ & $\begin{array}{l}\text { ME by spray } \\
\text { drying }\end{array}$ & $\begin{array}{l}\text { Chicken } \\
\text { nuggets }\end{array}$ & $\begin{array}{l}\text { Improvement of oxidative stability and preserving sensory } \\
\text { quality }\end{array}$ \\
\hline Fish oil & Konjac glucomannan & $\begin{array}{l}\text { ME by spray } \\
\text { drying }\end{array}$ & $\begin{array}{l}\text { Spanish } \\
\text { "salchichón" }\end{array}$ & $\begin{array}{l}\text { Fat content reduction ( } 30 \%) \text {, PUFA increment ( } 2 \%) \text { but } \\
\text { also lipid oxidation and altered sensory quality }\end{array}$ \\
\hline Fish oils & Sodium caseinate & $\begin{array}{l}\text { ME by freeze } \\
\text { drying }\end{array}$ & Ice cream & $\begin{array}{l}\text { Alteration of lipidic profile: SFA from } 65 \text { to } 46 \% \text {, MUFA } 28 \\
\text { to } 38 \% \text { and PUFA1 to } 3 \%\end{array}$ \\
\hline Fish oil & Not indicated & $\mathrm{ME}$ & $\begin{array}{l}\text { Microcapsul } \\
\text { powder }\end{array}$ & $\begin{array}{l}\text { elscrement of long chain } \omega 3 \text { PUFA concentration in blood } \\
\text { patients }\end{array}$ \\
\hline Fish oil & $\begin{array}{l}\text { Lecithin-chitosan and } \\
\text { maltodextrin }\end{array}$ & $\begin{array}{l}\text { ME by spray } \\
\text { drying }\end{array}$ & $\begin{array}{l}\text { Pork } \\
\text { meat } \\
\text { burgers }\end{array}$ & $\begin{array}{l}\text { Enrichment of pork meat with PUFAs, prevention of } \\
\text { oxidative reactions and organoleptic acceptance }\end{array}$ \\
\hline Microalgae & $\begin{array}{l}\text { Maltodextrin, gum } \\
\text { acacia, sodium } \\
\text { caseinate, starch }\end{array}$ & Spray drying & $\begin{array}{l}\text { Fruit } \\
\text { juice }\end{array}$ & $\begin{array}{l}\text { Enhancement of bioavailability, shelf life and oxidative } \\
\text { stability }\end{array}$ \\
\hline Chia oil & $\begin{array}{l}\text { Carnauba wax and } \\
\text { sodium caseinate }\end{array}$ & $\begin{array}{l}\text { ME by } \\
\text { freeze-drying }\end{array}$ & Cookies & $\begin{array}{l}\text { Increment of ALA to } 48 \%, \mathrm{AI} \text { and TI reduction. Sensory } \\
\text { acceptance. }\end{array}$ \\
\hline Flaxseed oil & Under patent & $\mathrm{ME}$ & Ice cream & $\begin{array}{l}\text { Increment of ALA. Fresh ice cream }(100 \mathrm{~g}) \text { meet } \sim 45 \% \\
\text { RDA ALA, at day } 120 \text { of storage it meets } \sim 35 \%\end{array}$ \\
\hline Flaxseed oil & $\begin{array}{l}\text { Gelatin, gum Arabic, } \\
\text { lactose, } \\
\text { transglutaminase }\end{array}$ & $\mathrm{ME}$ & Milk & $\begin{array}{l}\text { Improvement of oxidative stability but alteration of sensory } \\
\text { properties }\end{array}$ \\
\hline Flaxseed oil & $\begin{array}{l}\text { Saccharomyces } \\
\text { cerevisiae cells and } \\
\beta \text {-glucan }\end{array}$ & $\begin{array}{l}\text { ME by } \\
\text { freeze-drying }\end{array}$ & Bread & $\begin{array}{l}\text { Reduction of the peroxide index, increment of ALA } \\
\text { content, preservation of sensory properties }\end{array}$ \\
\hline $\begin{array}{l}\text { Chia, linseed } \\
\text { and chufa oils }\end{array}$ & $\begin{array}{l}\text { Sodium caseinate and } \\
\text { lactose }\end{array}$ & $\begin{array}{l}\text { ME by spray } \\
\text { drying }\end{array}$ & Deer pâté & $\begin{array}{l}\text { Reduction of cholesterol and SFA, increment of MUFAs } \\
\text { and PUFAs, modification of color and textures, but higher } \\
\text { oxidative instability }\end{array}$ \\
\hline $\begin{array}{l}\text { Virgin coconut } \\
\text { oil }\end{array}$ & $\begin{array}{l}\text { Soy protein and } \\
\text { lecithin }\end{array}$ & Emulsion & $\begin{array}{l}\text { Biodegradab } \\
\text { film }\end{array}$ & $\begin{array}{l}\text { lActive packaging with antioxidant capacity in olive oil } \\
\text { storage }\end{array}$ \\
\hline Clove oil & $\begin{array}{l}\text { Chicken feather } \\
\text { protein/pork gelatin }\end{array}$ & $\begin{array}{l}\text { Embedded in } \\
\text { protein/gelatin } \\
\text { matrix }\end{array}$ & $\begin{array}{l}\text { Gelatin } \\
\text { film }\end{array}$ & $\begin{array}{l}\text { Antioxidant and antimicrobial when used for storing } \\
\text { smoked salmon }\end{array}$ \\
\hline $\begin{array}{l}\text { Cinnamon, } \\
\text { rosemary and } \\
\text { basil EOs }\end{array}$ & Whey protein & $\begin{array}{l}\text { Embedded in } \\
\text { whey protein } \\
\text { matrix }\end{array}$ & \multicolumn{2}{|c|}{$\begin{array}{l}\text { Biodegradabletntioxidant and antimicrobial activities in fatty food } \\
\text { film simulant }\end{array}$} \\
\hline
\end{tabular}

Abbreviations: AI: atherogenic index, ALA: $\alpha$-linolenic acid, EOs: essential oils, ME: microencapsulation, MUFAs: monounsaturated fatty acids, PUFAs: polyunsaturated fatty acids, RDA: recommended dietary allowance, SFAs: saturated fatty acids, TI: thrombogenic index.

Thus, enzymatic hydrolysis is being an ideal way to recover oil from fish and fishery processing wastes with suitable enzyme and water. In most cases, alkaline/neutral proteases are used for the hydrolysis because they produce better results than the acidic proteases. The benefit of this method is can obtain large amount of oil compared to others methods due to the presence of enzymes that can catalyze the hydrolysis reaction process [184] . In addition, some of the last studies of SC-CO2 in a pilot-scale has revealed to be a promising process for the extraction of high amounts of oil from Colombian mango seed kernel, reaching oil yields of $83 \mathrm{~g} / \mathrm{kg}$ at $37 \mathrm{MPa}$ and $63^{\circ}$ $\mathrm{C}$ and an EFArich lipid fractions in LA $(37 \mathrm{~g} / \mathrm{kg})$ and ALA $(4 \mathrm{~g} / \mathrm{kg})$ acids [185].

Besides, from another perspective, the composition of the byproducts must be considered. The content of PUFA in plant seeds are being investigated as source of PUFA, however the concentration is lower than fish oil due to the absence of biosynthetic route in plants to produce DHA and EPA. Considerable efforts have been made to improve the composition of vegetable oil, and attempts have been made in producing DHA and EPA in plants by using algal, yeast, and bacterial genes involved in the PUFA synthesis [12]. Therefore, some studies are focused on the role of microorganisms and lipolytic enzymes over these products, as is the case of whole-crop oat silages and the alterations of the FAs profile motivated by these microbes [186]. On the other hand, a recent study used acidogenic fermentation to produce volatile FA from household food waste [187]. This way it could be used as a potential tool to manage this type of residues that are continuously growing. Taken all together, the utilization of agriculture and aquaculture by-products as a source of FAs still needs to face some challenges, mainly directed towards the optimization of the extraction and purification techniques and the improvement of the encapsulation 
and incorporation methodologies.

\section{CONCLUSIONS}

The search for economic and sustainable sources of PUFAs following the standards of circular economy is encouraged by their proven beneficial effects on health. The EFAs commercial products, represented by DHA and EPA, mainly derived from fish oil. Marine fishes are high in $\omega 3$ FAs, however high consumption of those fishes will cause a shortage of fish stocks existing naturally in the oceans. The search for alternative sources to get the recommended daily intake of $\omega 3$ FAs is the trend of today. There is a demand of more sustainable and cheaper $\omega 3$ sources like seeds. In addition, byproducts from the fish, crustacean, cereal and fruit and vegetable have been revealed as a source of high-value FA $\omega 3$ (DHA, EPA, ALA) and $\omega 6$ (LA), being a potent biomass to successfully develop additives rich in $\omega 3$ and useful to maintain the good ratio $\omega 6$ to $\omega 3$. Their applications will be probably connected to the optimum dietary intakes of FAs and future personalized nutrition by new formulations and functional foods. Thus, these strategies not only ensure more sustainable process, but also put in value new resources to extract and obtain different FA which could be further employed in the development of new industrial products without producing more wastes and economic losses

Oil extraction methods from food and food wastes include the traditional methods (ES, SxE, WP and CP) and improved nonconventional techniques (MAE, UAE, PLE, SFE and EAE) which have the potential to improve oil extraction yields while reduce extraction times and minimize deterioration of the oil quality. However, the majority studies carried out on the nonconventional methods of oil extraction have been focused on laboratory analyses. There is a need to extend the research and to scale up to industrial systems. As by-products have different nature, the FA extraction process needs to ensure the suitability of the technology from an economical and technical point of view. After extraction, LC fractionation allows to separate the oil components of interest according to their polarity and molecular weight, which are usually applied for the purification of $\omega 3$. The emulsion and encapsulation of FAs has been revealed as a promising tool to protect them from external agents involved in their fast oxidation and thus, it extends their chemical stability. Once stabilized, the nutritional properties of FA can be used to fortify different food matrixes to improve their lipidic profile. Besides, the use of these protective shells can be used to mask the odor or flavor that some FA possess and wider their applications while preventing negative sensorial impacts.

\section{ABBREVIATIONS}

Generic

FAO Food and Agriculture Organization of the United Nations

EE Ethyl Esters

ns Not specified

Fatty acids

FA Fatty Acid
FFA Free Fatty Acids

USFA Unsaturated Fatty Acid

MUFAs Monounsaturated Fatty Acids

PUFAs Polyunsaturated Fatty Acids

$\omega 3$ Omega-3

$\omega 6$ Omega-6

GLA $\gamma$-linolenic acid

ALA $\alpha$-Linolenic acid

DHA Docosahexaenoic acid

DPA Docosapentaenoic acid

EFAs Essential Fatty Acids

ETA Eicosatetraenoic acid

EPA Eicosapentaenoic acid

HTA Hexadecatrienoic acid

SA Stearic acid

SDA Stearidonic acid

Extraction and identification techniques

PLE Pressurized Liquid Extraction

MAE Microwave-Assisted Extraction

UAE Ultrasound-Assisted Extraction

EAE Enzyme Assisted Extraction

SWE Subcritical Water Extraction

SFE Super-Critical Fluid Extraction

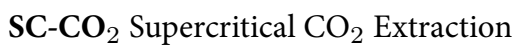

SE Solvent extraction

SxE Soxhlet Extraction

SFC Supercritical Fluid Chromatography

HHPE High Hydrostatic Pressure Extraction

HPLC High Resolution Liquid Chromatography

LC Liquid Chromatography

MS Mass Spectrometry

HPLC-MS High Resolution Liquid Chromatography-Mass Spectrometry

ESI Electrospray Ionization

APCI Atmospheric Pressure Chemical Ionization

TOF Time Of Flight

HPLC-MS/MS Tandem Mass Spectrometry

Ag-HPLC Silver Ion Chromatography

GC Gas Chromatography

FID Flame Ionization Detectors

ELSD Evaporative Light Scattering Detectors 
MD Molecular Distillation

CP Cold Pressed

WP Wet Pressing

\section{CONFLICTS OF INTEREST}

All authors declare there is no conflict of interest.

\section{ACKNOWLEDGEMENTS}

The research leading to these results was supported by MICINN supporting the Ramón y Cajal grant for M.A. Prieto (RYC2017-22891); by Xunta de Galicia for supporting the program EXCELENCIA-ED431F 2020/12, the post-doctoral grant of M. Fraga-Corral (ED481B-2019/096), the pre-doctoral grants of P. Garcia-Oliveira (ED481A-2019/295), M. Carpena (ED481A 2021/313) and A. Soria-Lopez (ED481A 2021/369). The authors are grateful to Ibero-American Program on Science and Technology (CYTED-AQUA-CIBUS, P317RT0003), to the Bio Based Industries Joint Undertaking (JU) under the grant agreements No. 888003 UP4HEALTH Project (H2020-BBI-JTI-2019) that supports the work of P. Otero and No. 790956 AQUABIOPRO-FIT "Aquaculture and agriculture biomass side stream proteins and bioactives for feed, fitness and health promoting nutritional supplements". The JU receives support from the European Union's Horizon 2020 research and innovation program and the Bio Based Industries Consortium. The project SYSTEMIC Knowledge hub on Nutrition and Food Security, has received funding from national research funding parties in Belgium (FWO), France (INRA), Germany (BLE), Italy (MIPAAF), Latvia (IZM), Norway $(\mathrm{RCN})$, Portugal (FCT), and Spain (AEI) in a joint action of JPI HDHL, JPI-OCEANS and FACCE-JPI launched in 2019 under the ERA-NET ERA-HDHL ( ${ }^{\circ}$ 696295).

\section{REFERENCES}

[1] Tvrzicka E, Kremmyda LS, Stankova B, Zak A. Fatty acids as biocompounds: Their role in human metabolism, health and disease - a review. part 1: Classification, dietary sources and biological functions. Biomedical Papers. 2011;155(2):117-130.

[2] Liu Y, Ramakrishnan VV, Dave D. Lipid class and fatty acid composition of oil extracted from Atlantic salmon by-products under different optimization parameters of enzymatic hydrolysis. Biocatalysis and Agricultural Biotechnology. 2020;30:101866101866.

[3] Guasch-Ferré M, Zong G, Willett WC, Zock PL, Wanders AJ, $\mathrm{Hu} \mathrm{FB}$, et al. Associations of monounsaturated fatty acids from plant and animal sources with total and cause-specific mortality in two us prospective cohort studies. Circulation Research. 2019;124(8):1266-1275.

[4] Li X, Bi X, Wang S, Zhang Z, Li F, Zhao AZ. Therapeutic potential of $\omega-3$ polyunsaturated fatty acids in human autoimmune diseases. Frontiers in Immunology. 2019;10:1-14.

[5] Siegert E, Paul F, Rothe M, Weylandt KH. The effect of omega-3 fatty acids on central nervous system remyelination in fat- 1 mice. BMC Neuroscience. 2017;18(1):1-9.

[6] Sokoła-Wysoczańska E, Wysoczański T, Wagner J, z KC, Bodkowski R, Lochyński S, et al. Polyunsaturated fatty acids and their potential therapeutic role in cardiovascular system disorders-a review. Nutrients. 2018;10(10):1-21.

[7] Singh J, Rasane P, Kaur S, Mca S. 2019.

[8] Szabó Z, Marosvölgyi T, Szabó E, Bai P, Figler M, Verzár Z. The Potential Beneficial Effect of EPA and DHA Supplementation Managing Cytokine Storm in Coronavirus Disease. Frontiers in Physiology. 2020;11:1-5.

[9] Trigo JP, Alexandre EMC, Saraiva JA, Pintado ME. High value-added compounds from fruit and vegetable byproducts-Characterization, bioactivities, and application in the development of novel food products. Critical Reviews in Food Science and Nutrition. 2020;60(8):1388-1416.

[10] Otero P, Saha SK, Gushin JM, Moane S. Identification of optimum fatty acid extraction methods for two different microalgae Phaeodactylum tricornutum and Haematococcus pluvialis for food and biodiesel applications. Analytical and Bioanalytical Chemistry. 2017;409:4659-4667.

[11] Santos HO, Price JC, Bueno AA. Beyond fish oil supplementation: The effects of alternative plant sources of omega-3 polyunsaturated fatty acids upon lipid indexes and cardiometabolic biomarkers-an overview. Nutrients. 2020;12(10):1-19.

[12] Khan A, Chun-Mei W, Khan H, Iqbal N, Lyu A, Shah SW, et al. Bioengineered Plants Can Be a Useful Source of Omega-3 Fatty Acids. BioMed Research International. 2017;.

[13] Finco AM, De O, Mamani LDG, Carvalho JC, De, Pereira GVDM, et al. Technological trends and market perspectives for production of microbial oils rich in omega-3. Critical Reviews in Biotechnology. 2016;

[14] Oliver L, Dietrich T, Marañón I, Villarán MC, Barrio RJ. Producing omega-3 polyunsaturated fatty acids: A review of sustainable sources and future trends for the EPA and DHA market. Resources. 2020;9(12):1-15.

[15] Dams S, Holasek S, Tsiountsioura M, Edelsbrunner M, Dietz P, Koefeler $\mathrm{H}$, et al. Effects of a plant-based fatty acid supplement and a powdered fruit, vegetable and berry juice concentrate on omega-3-indices and serum micronutrient concentrations in healthy subjects. International Journal of Food Sciences and Nutrition. 2020;71(6):769-780.

[16] Tan K, Ma H, Li S, Zheng H. Bivalves as future source of sustainable natural omega-3 polyunsaturated fatty acids. Food Chemistry. 2019;p. 125907-125907.

[17] Wang S, Zhu F, Kakuda Y. Sacha inchi (Plukenetia volubilis L.): Nutritional composition, biological activity, and uses. Food Chemistry. 2017;265:316-328.

[18] García-Oliveira P, Fraga-Corral M, Pereira AG, Prieto MA, Gandara J. Solutions for the sustainability of the food production and consumption system. Critical Reviews in Food Science and Nutrition. 2020;p. 1-18.

[19] Górnaś P, Rudzińska M, Raczyk M, Mišina I, Soliven A, Seglin, a D. Chemical Composition of Seed Oils Recovered from Different Pear (Pyrus communis L.) Cultivars. JAOCS. Journal of the American Oil Chemists' Society. 2016;93(2):267-274.

[20] Aung T, Halsey J, Kromhout D, Gerstein HC, Marchioli R, Tavazzi L, et al. Associations of omega-3 fatty acid supplement use with cardiovascular disease risks meta-analysis of 10 trials involving 77917 individuals. JAMA Cardiology. 2018;3(3):225234.

[21] Ciriminna R, Meneguzzo F, Delisi R, Pagliaro M. Enhancing and improving the extraction of omega-3 from fish oil. Sustainable Chemistry and Pharmacy. 2017;5:54-59.

[22] Fiori L, Solana M, Tosi P, Manfrini M, Strim C, Guella G. 2012. Available from: https://doi.org/10.1016/j.foodchem.2012.03.022. 
[23] Calder PC, Yaqoob P. Understanding Omega-3 Polyunsaturated Fatty Acids. Postgraduate Medical. 2009;121(6):148-157.

[24] FAO. 2020.

[25] Kandyliari A, Mallouchos A, Papandroulakis N, Golla JP, Lam TKT, Sakellari A, et al. Nutrient composition and fatty acid and protein profiles of selected fish by-products. Foods. 2020;9(2):114.

[26] Ucak I, Afreen M, Montesano D, Carrillo C, Tomasevic I, SimalGandara J, et al. Functional and Bioactive Properties of Peptides Derived from Marine Side Streams. Marine Drugs. 2021;19(2):115.

[27] Sun T, Pigott GM, Herwig RP. Lipase-assisted concentration of n-3 polyunsaturated fatty acids from viscera of farmed Atlantic salmon (Salmo salar L.). Journal of Food Science. 2002;67(1):130-136.

[28] Falch E, Rustad T, Jonsdottir R, Shaw NB, Dumay J, Berge JP, et al. Geographical and seasonal differences in lipid composition and relative weight of by-products from gadiform species. Journal of Food Composition and Analysis. 2006;19(6-7):727-736.

[29] Njinkoué JM, Barnathan G, Miralles J, Gaydou EM, Samb A. Lipids and fatty acids in muscle, liver and skin of three edible fish from the Senegalese coast: Sardinella maderensis, Sardinella aurita and Cephalopholis taeniops. Comparative Biochemistry and Physiology - B Biochemistry and Molecular Biology. 2002;131(3):506-507.

[30] Watanabe T, Murase T, Saito $H$. Specificity of fatty acid composition of highly migratory fish. A comparison of docosahexaenoic acid content in total lipids extracted in various organs of bonito (Euthynnus pelamis). Comparative Biochemistry and Physiology - Part B: Biochemistry And. 1995;111(4):691-695.

[31] Iñarra B, Bald C, Martín DS, Orive M, Cebrián M, Zufía J. 2018.

[32] Heu MS, Kim JS, Shahidi F. Components and nutritional quality of shrimp processing by-products. Food Chemistry. 2003;82(2):519-527.

[33] Beaulieu L, Thibodeau J, Bryl P, Carbonneau ME. Characterization of enzymatic hydrolyzed snow crab (Chionoecetes opilio) by-product fractions: A source of high-valued biomolecules. Bioresource Technology. 2009;100(13):3332-3342.

[34] Ahmad TB, Rudd D, Kotiw M, Liu L, Benkendorff K. Correlation between fatty acid profile and anti-inflammatory activity in common Australian seafood by-products. Marine Drugs. 2019;(3):17-17.

[35] Fao. Progresos en la lucha contra la pérdida y el desperdicio de alimentos. El Estado Del Mundo. 2019;32.

[36] Krishna AGG, Hemakumar KH, Khatoon S. Study on the composition of rice bran oil and its higher free fatty acids value. Journal of the American Oil Chemists' Society. 2006;83(2):117120.

[37] Górnaś P, Rudzińska M, Raczyk M, Soliven A. Lipophilic bioactive compounds in the oils recovered from cereal byproducts. Journal of the Science of Food and Agriculture. 2016;96(9):3256-3265.

[38] Kumar GS, Krishna AGG. Studies on the nutraceuticals composition of wheat derived oils wheat bran oil and wheat germ oil. Journal of Food Science and Technology. 2015;52(2):11451151.

[39] Panggat EB, Shindo J. Omega-3 fatty acids intended from the by-products processing of yellowfin tuna for sashimi. Fisheries Science. 2002;60(6):1434-1436.

[40] Mkadem H, Kaanane A. Recovery and Characterization of Fish Oil from By-products of Sardine (Sardina pilchardus) in the
Canning Process. Journal of Aquatic Food Product Technology. 2019;28(10):1037-1050.

[41] Rebolleda S, Beltrán S, Sanz MT, González-Sanjosé ML. Supercritical fluid extraction of wheat bran oil: Study of extraction yield and oil quality. European Journal of Lipid Science and Technology. 2014;116(3):319-327.

[42] Yilmaz I, Da囚lio囚lu O. The effect of replacing fat with oat bran on fatty acid composition and physicochemical properties of meatballs. Meat Science. 2003;65(2):286-289.

[43] Elleuch M, Besbes S, Roiseux O, Blecker C, Attia H. Quality characteristics of sesame seeds and by-products. Food Chemistry. 2007;103(2):641-650.

[44] Matthäus B, Özcan MM. Oil content, fatty acid composition and distributions of vitamin-E-active compounds of some fruit seed oils. Antioxidants. 2015;4(1):124-133.

[45] Górnaś P, Siger A, Segliṇa D. Physicochemical characteristics of the cold-pressed Japanese quince seed oil: New promising unconventional bio-oil from by-products for the pharmaceutical and cosmetic industry. Industrial Crops and Products. 2013;48:178-182.

[46] Martin ME, Grao-Cruces E, Millan-Linares MC, Paz SMDL. Grape (Vitis vinifera L.) seed oil: A functional food from the winemaking industry. Foods. 2020;9(10):1-20.

[47] Cantarelli PR, Palma ER. Physicochmical characteristics and Fatty Acids composition of tomato seed oil. Science Agriculture. 1993;50(1):117-120.

[48] Alves E, Rey F, Costa E, Da, Moreira ASP, Pato L, et al. Olive (Olea europaea L. cv. Galega vulgar) Seed Oil: A First Insight into the Major Lipid Composition of a Promising Agro-Industrial By-Product at Two Ripeness Stages. European Journal of Lipid Science and Technology. 2018;120(4):1-6.

[49] Kołakowska A, Domiszewski Z, Kozłowski D, Gajowniczek M. Effects of rainbow trout freshness on $\mathrm{n}-3$ polyunsaturated fatty acids in fish offal. European Journal of Lipid Science and Technology. 2006;108(9):723-729.

[50] Immanuel G, Sathasivan S, Shankar VS, Peter MJP, Palavesam A. Processing and characterisation of low cost Balistid fish Sufflamen capistratus liver oil for edible purpose. Food Chemistry. 2009;115(2):430-435.

[51] Chakraborty K, Joseph D. Cooking and pressing is an effective and eco-friendly technique for obtaining high quality oil from Sardinella longiceps. European Journal of Lipid Science and Technology. 2015;117(6):837-850.

[52] Khoddami A, Ariffin AA, Bakar J, Ghazali HM. Fatty Acid Profile of the Oil Extracted from Fish Waste (Head, Intestine and Liver) (Sardinella lemuru). World Applied Sciences Journal. 2009;7(1):127-131.

[53] Ixtaina VY, Martínez ML, Spotorno V, Mateo CM, Maestri DM, Diehl BWK, et al. Characterization of chia seed oils obtained by pressing and solvent extraction. Journal of Food Composition and Analysis. 2011;24(2):166-174.

[54] Rincón-Cervera MA, Villarreal-Rubio MB, Valenzuela R, Valenzuela A. Comparison of fatty acid profiles of dried and raw by-products from cultured and wild fishes. European Journal of Lipid Science and Technology. 2017;119(9):1-10.

[55] Chimsook T, Wannalangka W. 2015. Available from: https://doi. org/10.1051/matecconf/20153504001.

[56] Sathivel S, Prinyawiwatkul W, King JM, Grimm CC, Lloyd S. Microwave-assisted catfish liver oil extraction and FA analysis. Journal of the American Oil Chemists' Society. 2003;80(1):1520 . 
[57] Delfan-Hosseini S, Nayebzadeh K, Mirmoghtadaie L, Kavosi M, Hosseini SM. Effect of extraction process on composition, oxidative stability and rheological properties of purslane seed oil. Food Chemistry. 2017;222:61-66.

[58] Virot M, Tomao V, Ginies C, Visinoni F, Chemat F. Green procedure with a green solvent for fats and oils' determination. Microwave-integrated Soxhlet using limonene followed by microwave Clevenger distillation. Journal of Chromatography A. 2008;(1-2):147-152.

[59] Mello BD, Tais F, Garcia VADS, Silva C. UltrasoundAssisted Extraction of Oil from Chia (Salvia hispânica L.) Seeds: Optimization Extraction and Fatty Acid Profile. Journal of Food Process Engineering. 2017;40(1):1-8.

[60] Zhang ZS, Wang LJ, Li D, Jiao SS, Chen XD, Mao ZH. Ultrasound-assisted extraction of oil from flaxseed. Separation and Purification Technology. 2008;62(1):192-198.

[61] Long J, Fu Y, Zu Y, Li J, Wang W, Gu C, et al. Ultrasoundassisted extraction of flaxseed oil using immobilized enzymes. Bioresource Technology. 2011;102(21):9991-9996.

[62] Li T, Qu XY, Zhang QA, Wang ZZ. Ultrasound-assisted extraction and profile characteristics of seed oil from Isatis indigotica Fort. Industrial Crops and Products. 2012;35(1):98104.

[63] Cravotto G, Boffa L, Mantegna S, Perego P, Avogadro M, Cintas P. Improved extraction of vegetable oils under high-intensity ultrasound and/or microwaves. Ultrasonics Sonochemistry. 2008;15(5):898-902.

[64] Porto CD, Porretto E, Decorti D. Comparison of ultrasoundassisted extraction with conventional extraction methods of oil and polyphenols from grape (Vitis vinifera L.) seeds. Ultrasonics Sonochemistry. 2013;20(4):1076-1080.

[65] Luque-García JL, De L, Castro MD. Ultrasound-assisted Soxhlet extraction: An expeditive approach for solid sample treatment Application to the extraction of total fat from oleaginous seeds. Journal of Chromatography A. 2004;1034(1-2):237-242.

[66] Partan RU, Hidayat R. Exploration of seluang fish (Rasbora argyrotaenia) oil extraction methods by enzyme extraction and wet pressing with quality analysis. AACL Bioflux. 2020;13(4):2283-2289.

[67] Chantachum S, Benjakul S, Sriwirat N. Separation and quality of fish oil from precooked and non-precooked tuna heads. Food Chemistry. 2000;69(3):266-272.

[68] Honold PJ, Nouard ML, Jacobsen C. Fish oil extracted from fish-fillet by-products is weakly linked to the extraction temperatures but strongly linked to the omega-3 content of the raw material. European Journal of Lipid Science and Technology. 2016;118(6):874-884.

[69] zyńska AGR, Tynek M, Malinowska-Pańczyk E, Zurowska DM, Pawłowicz R, Kołodziejska I. Comparison of oil yield and quality obtained by different extraction procedures from salmon (Salmo salar) processing byproducts. European Journal of Lipid Science and Technology. 2016;118(11):1759-1767.

[70] Juhaimi A, Özcan F, Ghafoor MM, Babiker K, Hussain EE, S. Comparison of cold-pressing and soxhlet extraction systems for bioactive compounds, antioxidant properties, polyphenols, fatty acids and tocopherols in eight nut oils. Journal of Food Science and Technology. 2018;55(8):3163-3173.

[71] Sahena F, Zaidul ISM, Jinap S, Yazid AM, Khatib A, Norulaini NAN. Fatty acid compositions of fish oil extracted from different parts of Indian mackerel (Rastrelliger kanagurta) using various techniques of supercritical CO2 extraction. Food Chemistry. 2010;120(3):879-885.
[72] Dunford NT, Zhang M. Pressurized solvent extraction of wheat germ oil. Food Research International. 2003;36(9):99-100.

[73] Trentini CP, de Mello BTF, Cabral VF, da Silva C. Crambe seed oil: Extraction and reaction with dimethyl carbonate under pressurized conditions. Journal of Supercritical Fluids. 2020;159:104780.

[74] Villanueva-Bermejo D, Calvo MV, Castro-Gómez P, Fornari T, Fontecha J. Production of omega 3-rich oils from underutilized chia seeds. Comparison between supercritical fluid and pressurized liquid extraction methods. Food Research International. 2019;115:400-407.

[75] Monteiro A, Paquincha D, Martins F, Queirós RP, Saraiva JA, Švarc Gajić J, et al. Liquid by-products from fish canning industry as sustainable sources of $\omega 3$ lipids. Journal of Environmental Management. 2018;219:9-17.

[76] Otero P, López-Martínez MI, García-Risco MR. Application of pressurized liquid extraction (PLE) to obtain bioactive fatty acids and phenols from Laminaria ochroleuca collected in Galicia (NW Spain). Journal of Pharmaceutical and Biomedical Analysis. 2019;164:86-92.

[77] Castejón N, Luna P, Señoráns FJ. Alternative oil extraction methods from Echium plantagineum L. seeds using advanced techniques and green solvents. Food Chemistry. 2018;244:7582.

[78] Bendif H, Adouni K, Miara MD, e RB, Kraujalis P, Venskutonis $\mathrm{PR}$, et al. Essential oils (EOs), pressurized liquid extracts (PLE) and carbon dioxide supercritical fluid extracts (SFE-CO2) from Algerian Thymus munbyanus as valuable sources of antioxidants to be used on an industrial level. Food Chemistry. 2018;260:289298.

[79] Hao S, Wei Y, Li L, Yang X, Cen J, Huang H, et al. The effects of different extraction methods on composition and storage stability of sturgeon oil. Food Chemistry. 2015;173:274-282.

[80] Rubio-Rodríguez N, Diego SMD, Beltrán S, Jaime I, Sanz MT, Rovira J. Supercritical fluid extraction of fish oil from fish byproducts: A comparison with other extraction methods. Journal of Food Engineering. 2012;109(2):238-248.

[81] Solaesa AG, Sanz MT, Beltrán S, Melgosa R. Kinetic study and kinetic parameters of lipase-catalyzed glycerolysis of sardine oil in a homogeneous medium. Cuihua Xuebao/Chinese Journal of Catalysis. 2016;37(4):61040-61043.

[82] Lee JH, Asaduzzaman AKM, Yun JH, Yun JH, Chun BS. Characterization of the yellow croaker Larimichthys polyactis muscle oil extracted with supercritical carbon dioxide and an organic solvent. Fisheries and Aquatic Sciences. 2012;15(4):275281.

[83] Ferdosh S, Sarker ZI, Norulaini N, Oliveira A, Yunus K, Chowdury AJ, et al. Quality of Tuna Fish Oils Extracted from Processing the By-Products of Three Species of Neritic Tuna Using Supercritical Carbon Dioxide. Journal of Food Processing and Preservation. 2015;39(4):432-441.

[84] Porto CD, Decorti D, Tubaro F. Fatty acid composition and oxidation stability of hemp (Cannabis sativa L.) seed oil extracted by supercritical carbon dioxide. Industrial Crops and Products. 2012;36(1):401-404.

[85] Uribe JAR, Perez JIN, Kauil HC, Rubio GR, Alcocer CG. Extraction of oil from chia seeds with supercritical CO2. Journal of Supercritical Fluids. 2011;56(2):174-178.

[86] Pradhan RC, Naik SN, Rout PK, Dalai AK, Meda V. Supercritical carbon dioxide extraction of wheat distiller's dried grain with solubles. International Journal of Food Sciences and Nutrition. 2010;(8):829-836. 
[87] Abbas A, Anwar F, Ahmad N. Apple (Malus pumila) Seed Oil. Fruit Oils: Chemistry and Functionality. 2019;p. 495-504.

[88] Çakaloğlu B, Özyurt VH, Ötleş S. Cold press in oil extraction. A review. Ukrainian Food Journal. 2018;7(4):640-654.

[89] Koubaa M, Mhemdi H, Barba FJ, Roohinejad S, Greiner R, Vorobiev E. Oilseed treatment by ultrasounds and microwaves to improve oil yield and quality: An overview. Food Research International. 2016;85:59-66.

[90] Herrero M, Sánchez-Camargo P, Cifuentes A, Ibáñez E. Plants, seaweeds, microalgae and food by-products as natural sources of functional ingredients obtained using pressurized liquid extraction and supercritical fluid extraction. TrAC - Trends in Analytical Chemistry. 2015;71:26-38.

[91] Zhang QW, Lin LG, Ye WC. Techniques for extraction and isolation of natural products: A comprehensive review. Chinese Medicine (United Kingdom). 2018;13(1):1-26.

[92] Ivanovs K, Blumberga D. Extraction of fish oil using green extraction methods: A short review. Energy Procedia. 2017;128:477-483.

[93] Hewavitharana GG, Perera DN, Navaratne SB, Wickramasinghe I. Extraction methods of fat from food samples and preparation of fatty acid methyl esters for gas chromatography: A review. Arabian Journal of Chemistry. 2020;13(8):6865-6875.

[94] Folch J, Lees M, Sloane-Stanley GH. A simple method for the isolation and purification of total lipides from animal tissues. The Journal of Biological Chemistry. 1957;226(1):64849-64854.

[95] Bligh EG, Dyer WJ. A rapid method of total lipid extraction and purification. Canadian Journal of Biochemistry and Physiology. 1959;37(8):911-917.

[96] Aryee ANA, Simpson BK. Comparative studies on the yield and quality of solvent-extracted oil from salmon skin. Journal of Food Engineering. 2009;92(3):353-358.

[97] Bonilla-Mendez JR, Hoyos-Concha JL. Methods of extraction, refining and concentration of fish oil as a source of omega3 fatty acids. Corpoica Ciencia y Tecnologia Agropecuaria. 2018;19(3):645-668.

[98] Breil C, Vian MA, Zemb T, Kunz W, Chemat F. Bligh and Dyer" and Folch methods for solid-liquid-liquid extraction of lipids from microorganisms. Comprehension of solvatation mechanisms and towards substitution with alternative solvents. International Journal of Molecular Sciences. 2017;18(4):1-21.

[99] Zhang Z, Richardson CE, Hennebelle M, Taha AY. Validation of a One-Step Method for Extracting Fatty Acids from Salmon, Chicken and Beef Samples. Journal of Food Science. 2017;82(10):2291-2297.

[100] Dave D, Routray W. Current scenario of Canadian fishery and corresponding underutilized species and fishery byproducts: A potential source of omega-3 fatty acids. Journal of Cleaner Production. 2018;180:617-641.

[101] Rubio-Rodríguez N, Beltrán S, Jaime I, Diego SMD, Sanz MT, Carballido JR. 2010. Available from: https://doi.org/10.1016/j. ifset.2009.10.006.

[102] Sundrasegaran S, Mah SH. Extraction Methods of Virgin Coconut Oil and Palm-pressed Mesocarp Oil and their. Phytonutrients EFood. 2020;1(6):381-381.

[103] López-Bascón-Bascon MA, Castro MDLD. 2019. Available from: https://doi.org/10.1016/B978-0-12-816911-7.00011-6.

[104] Zygler A, Słomińska M, Namieśnik J. Soxhlet extraction and new developments such as soxtec. Comprehensive Sampling and Sample Preparation. 2012;2:65-82.

[105] Melgosa R, Sanz MT, Beltrán S. Supercritical CO2 processing of omega-3 polyunsaturated fatty acids - Towards a biorefinery for fish waste valorization. Journal of Supercritical Fluids.
2021;169:105121-105121.

[106] Yusuf AK. a Review of Methods Used for. International Journal of Science and Research. 2017;8(7):1854-1861.

[107] Özcan MM, Rosa A, Dessi MA, Marongiu B, Piras A, Al-Juhaimi FYI. Quality of wheat germ oil obtained by cold pressing and supercritical carbon dioxide extraction. Czech Journal of Food Sciences. 2013;31(3):236-240.

[108] Fouda T. Using Green Cold Pressing to Produce High Quality Fish Oil From Industrial Salmon Waste. Journal of Zoological Research. 2020;2(1).

[109] Stroescu M, Stoica-Guzun A, Ghergu S, Chira N, Jipa I. Optimization of fatty acids extraction from Portulaca oleracea seed using response surface methodology. Industrial Crops and Products. 2013;43(1):405-411.

[110] Khoomrung S, Chumnanpuen P, Jansa-Ard S, Staišhlman M, Nookaew I, Borén J, et al. Rapid quantification of yeast lipid using microwave-assisted total lipid extraction and HPLC-CAD. Analytical Chemistry. 2013;85(10):4912-4919.

[111] Mercer P, Armenta RE. Developments in oil extraction from microalgae. European Journal of Lipid Science and Technology. 2011;113(5):539-547.

[112] Akhtar HH. Comparison of microwave assisted extraction with conventional (homogenization, vortexing) for the determination of incurred salinomycin in chicken eggs and tissues. Journal of Environmental Science and Health - Part B Pesticides, Food Contaminants, and Agricultural Wastes. 2004;39(5-6):835-844.

[113] Routray W, Orsat V. Microwave-Assisted Extraction of Flavonoids: A. Review Food and Bioprocess Technology. 2012;5(2):409-424.

[114] Roselló-Soto E, Galanakis CM, Brnčić M, Orlien V, Trujillo FJ, Mawson R, et al. Clean recovery of antioxidant compounds from plant foods, by-products and algae assisted by ultrasounds processing. Modeling approaches to optimize processing conditions. Trends in Food Science and Technology. 2015;42(2):134-149.

[115] Xu DP, Zheng J, Zhou Y, Li Y, Li S, Li H, et al. Ultrasoundassisted extraction of natural antioxidants from the flower of Limonium sinuatum: Optimization and comparison with conventional methods. Food Chemistry. 2017;217:552-559.

[116] Yilmaz FM, Görgüç A, Gençdağ E. Recovery and Purification of Antioxidant Compounds from Plant Origin Agro-Industrial By-products. In: Ekiert H, Ramawat K, Arora J, editors. Plant Antioxidants and Health. Springer; 2021. p. 1-24.

[117] Doan MTN, Huynh MC, Pham ANV, Chau NDQ, Le PTK. Extracting seed oil and phenolic compounds from papaya seeds by ultrasound-assisted extraction method and their properties. Chemical Engineering Transactions. 2020;78:493-498.

[118] Castejón N, Luna P, Señorans FJ. Ultrasonic removal of mucilage for pressurized liquid extraction of omega-3 rich oil from chia seeds (Salvia Hispanica L.). Journal of Agricultural and Food Chemistry. 2017;65(12):2572-2579.

[119] Kadam SU, Tiwari BK, Donnell CP. Application of novel extraction technologies for bioactives from marine algae. Journal of Agricultural and Food Chemistry. 2013;(20):4667-4675.

[120] Wang L, Weller CL. Recent advances in extraction of nutraceuticals from plants. Food Science and Technology. 2006;17:300-312.

[121] Herrero M, Castro-Puyana M, Mendiola JA, Ibañez E. Compressed fluids for the extraction of bioactive compounds. TrAC - Trends in Analytical Chemistry. 2013;43(2):67-83.

[122] Mendiola JA, Herrero M, Cifuentes A, Ibañez E. Use of compressed fluids for sample preparation: Food applications. 
Journal of Chromatography A. 2007;1152(1-2):234-246.

[123] Alvarez-Rivera G, Bueno M, Ballesteros-Vivas D, Mendiola JA, Ibañez E. Pressurized liquid extraction. Liquid-Phase Extraction. 2019;p. 375-398.

[124] Otero P, Quintana SE, Reglero G, Fornari T, García-Risco MR. Pressurized Liquid Extraction (PLE) as an innovative green technology for the effective enrichment of galician algae extracts with high quality fatty acids and antimicrobial and antioxidant properties. Marine Drugs. 2018;16(5):156-156.

[125] Marić B, Pavlić B, Čolović D, Abramović B, Zeković Z, BodrožaSolarov M, et al. Recovery of high-content $\omega$-3 fatty acid oil from raspberry (Rubus idaeus L.) seeds: Chemical composition and functional quality. LWT. 2020;130:109627-109627.

[126] Akanda MJH, Sarker MZI, Ferdosh S, Manap MYA, Rahman NNNA, Kadir MOA. Applications of supercritical fluid extraction (SFE) of palm oil and oil from natural sources. Molecules. 2012;17(2):1764-1794.

[127] Zougagh M, Valcárcel M, Ríos A. Supercritical fluid extraction: A critical review of its analytical usefulness. TrAC - Trends in Analytical Chemistry. 2004;23(5):399-405.

[128] Lembke P. Production techniques for omega-3 concentrates. Omega-6/3 Fatty Acids: Functions, Sustainability Strategies and Perspectives. 2013;p. 353-364.

[129] Shahidi F, Wanasundara UN. Omega-3 fatty acid concentrates: Nutritional aspects and production technologies. Trends in Food Science and Technology. 1998;9(6):230-240.

[130] Sahena F, Zaidul ISM, Jinap S, Saari N, Jahurul HA, Abbas KA, et al. PUFAs in fish: Extraction, fractionation, importance in health. Comprehensive Reviews in Food Science and Food Safety. 2009;8(2):59-74.

[131] Dillon JT, Aponte JC, Tarozo R, Huang Y. Purification of omega-3 polyunsaturated fatty acids from fish oil using silverthiolate chromatographic material and high performance liquid chromatography. Journal of Chromatography A. 2013;1312:1825.

[132] Tiegs C, Riha V, Brunner G, Steiner K. Separation of multicomponent mixtures of fatty acid ethyl esters from Fish oil by current SFE. Process Technology Proceedings. 1996;12(C):80050-80051.

[133] Pettinello G, Bertucco A, Pallado P, Stassi A. Production of EPA enriched mixtures by supercritical fluid chromatography: From the laboratory scale to the pilot plant. Journal of Supercritical Fluids. 2000;19(1):72-75.

[134] Brondz I. Development of fatty acid analysis by highperformance liquid chromatography, gas chromatography, and related techniques. Analytica Chimica Acta. 2002;465(1-2):1-37.

[135] Hidajat K, Ching CB, Rao MS. Preparative-scale liquid chromatographic separation of $\omega-3$ fatty acids from fish oil sources. Journal of Chromatography A. 1995;702(1-2):215-221.

[136] Rao MS, Hidajat K, Ching CB. Reversed-phase hplc: the separation method for the characterization and purification of long chain polyunsaturated fatty acids-review. Journal of Chromatographic Science. 1995;33(1):9-21.

[137] Bernal JL, Martín MT, Toribio L. Supercritical fluid chromatography in food analysis. Journal of Chromatography A. 2013;1313:24-36.

[138] Viswanathan S, Verma PRP, Ganesan M, Manivannan J. A novel liquid chromatography/tandem mass spectrometry (LCMS/MS) based bioanalytical method for quantification of ethyl esters of Eicosapentaenoic acid (EPA) and Docosahexaenoic acid (DHA) and its application in pharmacokinetic study. Journal of Pharmaceutical and Biomedical Analysis. 2017;141:250-261.
[139] Dołowy M, Pyka A. Chromatographic methods in the separation of long-chain mono- and polyunsaturated fatty acids. Journal of Chemistry. 2015;p. 120830-120830.

[140] Jiao G, Hui JPM, Burton IW, Thibault MH, Pelletier C, Boudreau J, et al. Characterization of shrimp oil from Pandalus borealis by high performance liquid chromatography and high resolution mass spectrometry. Marine Drugs. 2015;13(6):3849-3876.

[141] Czajkowska-Mysłek A, Siekierko U, Gajewska M. Application of Silver Ion High-Performance Liquid Chromatography for Quantitative Analysis of Selected n-3 and n-6 PUFA in Oil Supplements. Lipids. 2016;51(4):413-421.

[142] Herrera C, Ramaley L, Potvin L, Melanson MA, E J. A method for determining regioisomer abundances of polyunsaturated triacylglycerols in omega-3 enriched fish oils using reversed-phase liquid chromatography and triple-stage mass spectrometry. Food Chemistry. 2013;139(1-4):655-662.

[143] Alkio M. VTT Publications. 2007.

[144] Yang Y, Liang Y, Yang J, Ye F, Zhou T, Gongke L. Advances of supercritical fluid chromatography in lipid profiling. Journal of Pharmaceutical Analysis. 2019;9(1):1-8.

[145] Señoráns FJ, Ibañez E. Analysis of fatty acids in foods by supercritical fluid chromatography. Analytica Chimica Acta. 2002; 465(1-2):208-216.

[146] Gharibzahedi SMT, George S, Greiner R, Estevinho BN, Fernández MJF, Mcclements DJ, et al. New Trends in the Microencapsulation of Functional Fatty Acid-Rich Oils Using Transglutaminase Catalyzed Crosslinking. Comprehensive Reviews in Food Science and Food Safety. 2018;17(2):274-289.

[147] Ricaurte L, Perea-Flores M, De J, Martinez A, QuintanillaCarvajal MX. 2016. Available from: https://doi.org/https://doi. org/10.1016/j.ifset.2016.04.004.

[148] Lu GW, Gao P. Emulsions and Microemulsions for Topical and Transdermal Drug Delivery. Handbook of Non-Invasive Drug Delivery Systems. 2010;p. 59-94.

[149] Selani MM, Shirado GAN, Margiotta GB, Rasera ML, Marabesi AC, Piedade SMS, et al. Pineapple by-product and canola oil as partial fat replacers in low-fat beef burger: Effects on oxidative stability, cholesterol content and fatty acid profile. Meat Science. 2016;115:9-15.

[150] Pintado T, Ruiz-Capillas C, Jiménez-Colmenero F, Herrero AM. 2020. Available from: https://doi.org/10.3390/foods9121847.

[151] Urgu-Öztürk M, Öztürk-Kerimoğlu B, Serdaroğlu M. Design of healthier beef sausage formulations by hazelnut-based pre-emulsion systems as fat substitutes. Meat Science. 2020;167:108162-108162.

[152] Paglarini C, De S, Martini S, Pollonio MAR. Using emulsion gels made with sonicated soy protein isolate dispersions to replace fat in frankfurters. LWT. 2019;99:453-459.

[153] Öztürk-Kerimoğlu B, Kara A, Urgu-Öztürk M, Serdaroğlu M. 2021. Available from: https://doi.org/https://doi.org/10.1016/j. lwt.2020.110044.

[154] Gharehcheshmeh MH, Arianfar A, Mahdian E, Naji-Tabasi S. Production and evaluation of sweet almond and sesame oil nanoemulsion and their effects on physico-chemical, rheological and microbial characteristics of enriched yogurt. Journal of Food Measurement and Characterization. 2020;

[155] El-Kholy WM, Soliman TN, Darwish AMG. Evaluation of date palm pollen (Phoenix dactylifera L.) encapsulation, impact on the nutritional and functional properties of fortified yoghurt. PLoS ONE. 2019;14(10).

[156] Zhong J, Yang R, Cao X, Liu X, Qin X. Improved Physicochemical Properties of Yogurt Fortified with Fish Oil $/ \gamma$-Oryzanol by Nanoemulsion Technology. Molecules. 2018;(1):23-23. 
[157] Ricaurte L, Santagapita PR, Díaz LE, Quintanilla-Carvajal MX. Edible gelatin-based nanofibres loaded with oil encapsulating high-oleic palm oil emulsions. Colloids and Surfaces A: Physicochemical and Engineering Aspects. 2020;595:124673124673.

[158] Geranpour M, Assadpour E, Jafari SM. Recent advances in the spray drying encapsulation of essential fatty acids and functional oils. Trends in Food Science \& Technology. 2020;102:71-90.

[159] Risch SJ. Encapsulation: Overview of Uses and Techniques. Encapsulation and Controlled Release of Food Ingredients. 1995;590:1-2.

[160] Jiménez-Martín E, Pérez-Palacios T, Carrascal JR, Rojas TA. Enrichment of Chicken Nuggets with Microencapsulated Omega-3 Fish Oil: Effect of Frozen Storage Time on Oxidative Stability and Sensory Quality. Food and Bioprocess Technology. 2016;9(2):285-297.

[161] Lorenzo JM, Munekata PES, Pateiro M, Campagnol PCB, Domínguez R. Healthy Spanish salchichón enriched with encapsulated $n-3$ long chain fatty acids in konjac glucomannan matrix. Food Research International. 2016;89:289-295.

[162] Andajani PT. Microencapsulated mixture of fish oil and fortified in ice cream. Jurnal Ilmu Dan Teknologi Hasil Ternak (JITEK). 2017;11(2):1-10.

[163] Hinriksdottir HH, Jonsdottir VL, Sveinsdottir K, Martinsdottir E, Ramel A. Bioavailability of long-chain n-3 fatty acids from enriched meals and from microencapsulated powder. European Journal of Clinical Nutrition. 2015;69(3):344-348.

[164] Aquilani C, Pérez-Palacios T, Martín EJ, Antequera T, Bozzi R, Pugliese C. Effetto del tipo di conservazione e arricchimento in omega-3 sulla qualità di hamburger di Cinta Senese. Archivos de Zootecnia. 2018;67:217-220.

[165] Singh H, Kumar C, Singh N, Paul S, Jain SK. Nanoencapsulation of docosahexaenoic acid (DHA) using a combination of food grade polymeric wall materials and its application for improvement in bioavailability and oxidative stability. Food \& Function. 2018;9(4):2213-2227.

[166] Venturini LH, Moreira TFM, Silva TBVD, Almeida MMCD, Francisco CRL, Oliveira AD, et al. Partial Substitution of Margarine by Microencapsulated Chia Seeds Oil in the Formulation of Cookies. Food and Bioprocess Technology. 2019;12(1):77-87.

[167] Gowda A, Sharma V, Goyal A, Singh AK, Arora S. Process optimization and oxidative stability of omega-3 ice cream fortified with flaxseed oil microcapsules. Journal of Food Science and Technology. 2018;55(5):1705-1715.

[168] Ghorbanpour A, Nasirpour A, Goli AH, Tayebi M. Sensory and Physico-chemical Properties of Enriched Milk with Microencapsulated Flaxseed Oil. Iranian-J-Nutr-Sci-FoodTechnol. 2017;11(4):129-138.

[169] Beikzadeh S, Shojaee-Aliabadi S, Dadkhodazade E, Sheidaei Z, Abedi AS, Mirmoghtadaie L, et al. Comparison of Properties of Breads Enriched with Omega-3 Oil Encapsulated in $\beta$ Glucan and Saccharomyces cerevisiae Yeast Cells. Applied Food Biotechnology. 2019;7(1):11-20.

[170] Vargas-Ramella M, Pateiro M, Barba FJ, Franco D, Campagnol PCB, Munekata PES, et al. Microencapsulation of healthier oils to enhance the physicochemical and nutritional properties of deer pâté. LWT. 2020;125:109223-109223.

[171] Carpiné D, Dagostin JLA, Bertan LC, Mafra MR. Development and Characterization of Soy Protein Isolate Emulsion-Based Edible Films with Added Coconut Oil for Olive Oil Packaging:
Barrier, Mechanical, and Thermal Properties. Food and Bioprocess Technology. 2015;8(8):1811-1823.

[172] Song NB, Lee JH, Mijan MA, Song K, Bin. Development of a chicken feather protein film containing clove oil and its application in smoked salmon packaging. LWT - Food Science and Technology. 2014;57(2):453-460.

[173] Ribeiro-Santos R, Sanches-Silva A, Motta JFG, Andrade M, Neves A, Teófilo RF, et al. Combined use of essential oils applied to protein base active food packaging: Study in vitro and in a food simulant. European Polymer Journal. 2017;93:75-86.

[174] Ullah R, Nadeem M, Imran M, Khan MK, Mushtaq Z, Asif $\mathrm{M}$, et al. Effect of microcapsules of chia oil on $\Omega-3$ fatty acids, antioxidant characteristics and oxidative stability of butter. Lipids in Health and Disease. 2020;19(1).

[175] Umesha SS, Manohar RS, Indiramma AR, Akshitha S, Naidu KA. Enrichment of biscuits with microencapsulated omega-3 fatty acid (Alpha-linolenic acid) rich Garden cress (Lepidium sativum) seed oil: Physical, sensory and storage quality characteristics of biscuits. LWT - Food Science and Technology. 2015;62(1):654-661.

[176] Bermúdez-Aguirre D, Barbosa-Cánovas GV, V G. 2011. Available from: https://doi.org/10.1016/j.lwt.2011.01.023.

[177] Ghorbanzade T, Jafari SM, Akhavan S, Hadavi R. Nanoencapsulation of fish oil in nano-liposomes and its application in fortification of yogurt. Food Chemistry. 2017;216:146-152.

[178] Estrada JD, Boeneke C, Bechtel P, Sathivel S. Developing a strawberry yogurt fortified with marine fish oil 1 . Journal of Dairy Science. 2011;(12):94-94.

[179] Gulzar S, Benjakul S. Fortification of Skim Milk with Nanoliposomes Loaded with Shrimp Oil: Properties and Storage Stability. Journal of the American Oil Chemists' Society. 2020;97(8):929-940.

[180] Pike IH, Jackson A. Fish oil: Production and use now and in the future. Lipid Technology. 2010;22(3):59-61.

[181] Gebreyowhans S, Lu J, Zhang S, Pang X, Lv J. Dietary enrichment of milk and dairy products with n-3 fatty acids: A review. International Dairy Journal. 2019;97:158-166.

[182] Nienaber A, Ozturk M, Dolman RC, Zandberg L, Hayford FE, Brombacher F, et al. Beneficial effect of long-chain n-3 polyunsaturated fatty acid supplementation on tuberculosis in mice. Prostaglandins Leukotrienes and Essential Fatty Acids. 2021;170:102304-102304.

[183] Vegneshwaran VR, D D. Investigation on Oil Extraction Methods and its Influence on Omega-3 Content from Cultured Salmon. Journal of Food Processing \& Technology. 2014;5(12).

[184] Iberahim NI, Hamzah Z, Yin YJ, Sohaimi KSA. Extraction and Characterization of Omega-3 Fatty Acid from Catfish Using Enzymatic Hydrolysis Technique. MATEC Web of Conferences. 2018;187:01005.

[185] Cerón-Martínez LJ, Hurtado-Benavides AM, Ayala-Aponte A, Serna-Cock L, Tirado DF. A pilot-scale supercritical carbon dioxide extraction to valorize colombian mango seed kernel. Molecules. 2021;(8):26-26.

[186] Liu QH, Wu JX, Shao T. Roles of microbes and lipolytic enzymes in changing the fatty acid profile, $\alpha$-tocopherol and $\beta$-carotene of whole-crop oat silages during ensiling and after exposure to air. Animal Feed Science and Technology. 2019;253:81-92.

[187] Strazzera G, Battista F, Tonanzi B, Rossetti S, Bolzonella D. Optimization of short chain volatile fatty acids production from household food waste for biorefinery applications. Environmental Technology and Innovation. 2021;23:101562101562. 